\title{
ETHNIC IDENTITY AND CULTURAL MISATTRIBUTION IN EARLY OTTOMAN PHOTOGRAPHY
}

by

\author{
Cassandra Tavukciyan
}

Bachelor of Fine Arts, Emily Carr University, Vancouver BC, 2014

\author{
A thesis \\ presented to Ryerson University \\ in partial fulfillment of the \\ requirements for the degree of \\ Master of Arts \\ in the Program of
}

Film and Photography Preservation and Collections Management

Toronto, Ontario, Canada, 2017

(C) Cassandra Tavukciyan 2017 


\section{AUTHOR'S DECLARATION FOR ELECTRONIC SUBMISSION OF A THESIS}

I hereby declare that I am the sole author of this thesis. This is a true copy of the thesis, including any required final revisions, as accepted by my examiners.

I authorize Ryerson University to lend this thesis to other institutions or individuals for the purpose of scholarly research.

I further authorize Ryerson University to reproduce this thesis by photocopying or by other means, in total or in part, at the request of other institutions or individuals for the purpose of scholarly research.

I understand that my thesis may be made electronically available to the public. 


\begin{abstract}
Ethnic Identity and Cultural Misattribution in Early Ottoman Photography Master of Arts 2017

Cassandra Tavukciyan

Film and Photographic Preservation and Collections Management, Ryerson University
\end{abstract}

When photography was first introduced in the Ottoman Empire, Islamic laws forbade the production of images of sentient beings and therefore the practice of photography to the Muslim majority. Non-Muslim minorities, in particular the Armenians, thus became significant producers of photographic practices and traditions in the late Ottoman Empire. Until the present, however, cataloguing practices have not reflected the complexity of Ottoman society, resulting in an inadequate if not misleading representation of Armenian photographers, and their contributions. Using the photographs of Gabriel Lekegian, Pascal Sébah and Jean Pascal Sébah housed in the New York Public Library this thesis investigates the extent to which the Armenian community was involved with the development, production and circulation of Ottoman photography and argues for the inclusion of their ethnic identities in catalogue records so as to begin to identify the distinct characteristics or aesthetic qualities inherent in the Armenian photographic tradition. 


\section{Acknowledgements}

I am grateful for the involvement of many people throughout this entire project. They have enriched my research process with encouraging conversations and thoughtful advice.

First, I must thank my first reader Marta Braun, FPPCM Program Director and Professor, School of Image Arts, Ryerson University, whose constructive feedback and unwavering enthusiasm for this thesis strengthened the outcome of my overall research and writing. Gratitude is also due to my second reader, Dr. Armen Marsoobian, Professor of Philosophy and Chairperson of the Philosophy Department at Southern Connecticut State University, whose warm generosity and specialized knowledge on Armenian photography in Ottoman Anatolia was invaluable towards this thesis. I must also thank Don Snyder, Professor, School of Image Arts, Ryerson for the taking the time to review my thesis throughout its different stages.

Thanks are also due to several of my colleagues at the New York Public Library who kindly offered their knowledge, feedback, and their time: Joshua Chuang, Miriam \& Ira D. Wallach Associate Director for Arts, Prints and Photographs, Dr. Elizabeth Cronin, Assistant Curator of Photography, Zulay Chang, Photography Specialist II and David Lowe, Photography Specialist I. I must also thank Dr. Peter Balakian, Donald M. and Constance H. Rebar Professor of Humanities at Colgate University, Dr. Joe Malikian, founder of The Middle East and Armenian Photograph Project (MEAPP), and Peter Constantine for taking the time to share their knowledge with both Ottoman and Armenian culture and history.

To my family I would like to extend my sincerest gratitude for their support. Most of all, thank you to Patrick for his constant encouragement, support, and love. I would not be where I am today without you. 


\section{Table of Contents}

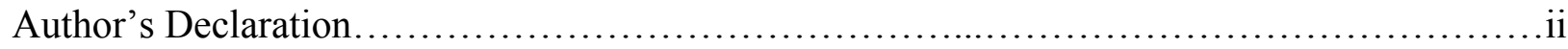

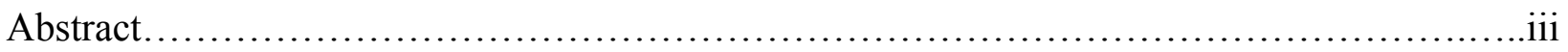

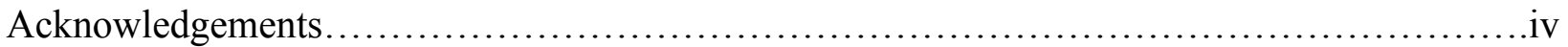

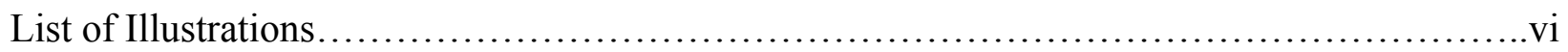

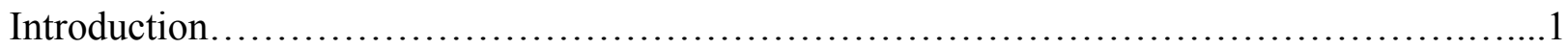

1. Literature Survey...........................................................

2. The Historical Context.............................................................. 13

3. Case Study: Gabriel Lekegian.................................................20

4. Case Study: Pascal Sébah and Jean Pascal Sébah....................................... 35

5. Conclusion ................................................................... 51

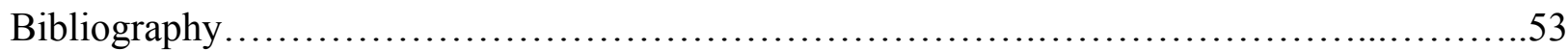




\section{List of Illustrations}

1. Gabriel Lekegian, Porteuse d'eau a Constantinople (c.1880)...........................25

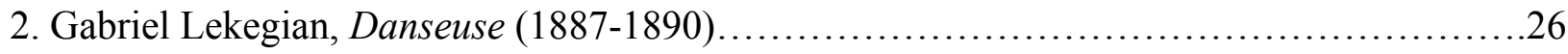

3. Gabriel Lekegian, [Girl in Ceremonial Dress] (1887-1890).............................27

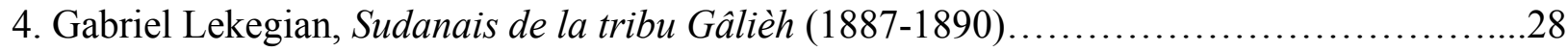

5. Gabriel Lekegian, Sacca (service d'eau à domicile) (1887-1890)..........................29

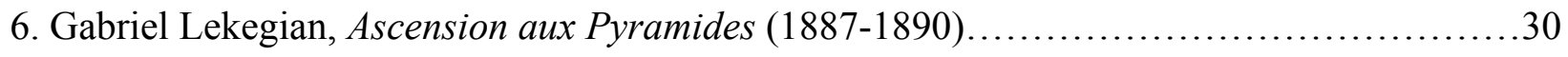

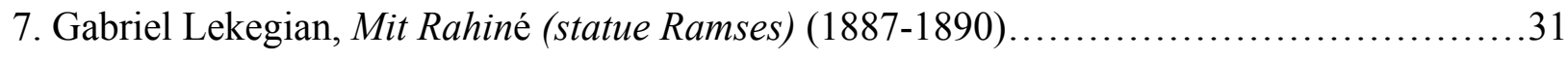

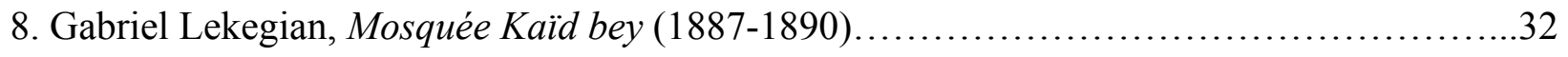

9. Gabriel Lekegian, Sphinx de Ghizeh No. 10. (1887-1890)...............................33

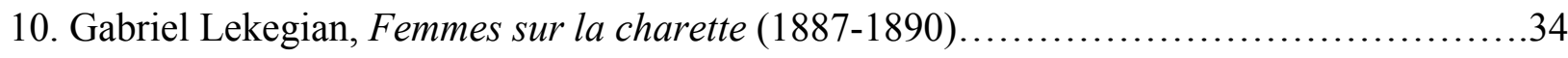

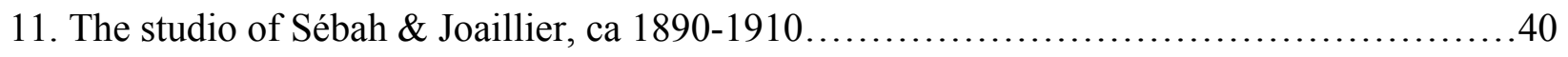

12. Pascal Sébah, Constantinople: Armenian Bride (circa 1873)........................41

13. Pascal Sébah, The Fountain of Sultan Ahmet III in Istanbul, detail (circa 1870)............42

14. Jean Pascal Sébah, [Two men, woman and boy by carved door] (1888-1900)..............43

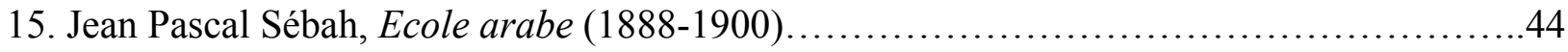

16. Jean Pascal Sébah, Mosque of Sultan Hassan, interior (1888-1900)......................45

17. Jean Pascal Sébah, Sakieh (système d'irrigation) (1888-1900)..........................46

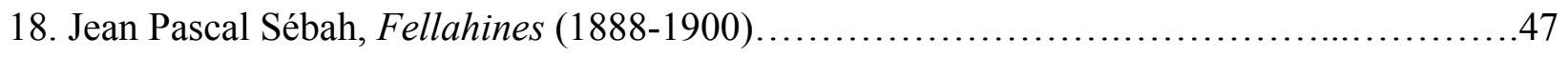

19. Jean Pascal Sébah, Mosq. Mohamed Ali (Chaire) (1888-1900)..........................48

20. Jean Pascal Sébah, Sphinx Armachis [neg.232] (1888-1900).........................49

21. Jean Pascal Sébah, Pyramide Cheops: ascension [neg.229] (1888-1900)..................50 


\section{Introduction}

Ottoman photography has been frequently studied without addressing a basic puzzle regarding the nature of photographic production in late modern Islamic society. Namely, how was it possible that a state and society based on Islamic law and norms which placed strong constraints on the production and consumption of images of living beings — aniconism — could develop an indigenous photographic industry and market? This thesis argues that an understanding of the role of non-Muslim minorities in the Ottoman Empire, specifically the contributions made by ethnic Armenians, can offer greater insight into the nature of the indigenous production of images in the Middle East. Indeed, without a fuller awareness of the role of non-Muslim indigenous minorities in the photographic life of the Empire, our understanding of these images risks remaining partial at best, and, at worst, Orientalist. ${ }^{1}$

While indigenous photographic practitioners in the Ottoman Empire are beginning to be recognized in scholarly research and literature, their ethnic identities are often incorrectly attributed or entirely missing from their accompanying catalogue records. The result is a failure to recognize their contributions to Ottoman photographic practices, traditions and styles. Using case studies of photographic works by Ottoman photographers Gabriel Lekegian (1853-1920) Pascal Sébah (1823-1886) and Jean Pascal Sébah (1872-1947) housed in the New York Public Library’s Miriam and Ira D. Wallach Division of Art, Prints and Photographs Collection, this thesis addresses such misattributions in order to help bring greater awareness to the societal role of ethnic minorities in the Ottoman Empire and to further clarify and illuminate their contribution to photographic practices.

\footnotetext{
${ }^{1}$ Stephen Sheehi, introduction to The Arab Imago: Social History of Portrait Photography (New Jersey: Princeton University Press, 2016), xx-xxi.
} 
Such misattributions are not uncommon in the history of Ottoman photographic culture, as many local Ottoman photographers chose to associate themselves with either their clientele (European) or the majority culture (Ottoman-Turkish). For instance, ethnically Armenian photographer Gabriel Lekegian is commonly recognized as "French," although he never lived or worked in France. Similarly, Ottoman photographers Pascal Sébah and Jean Pascal Sébah are largely recognized as "Turkish", while in fact, they were ethnically Syrian-Armenian. While it is not clear exactly why these photographers have been catalogued in such a way, by examining the Armenian community's involvement in Ottoman photography and highlighting the biographical details of Lekegian, and the Sébah family, this thesis aims to develop a more well-rounded understanding of minority photographic traditions in the Ottoman Empire that are not as fully recognized as Western or European ones.

For over 600 years, the Ottoman Empire had substantial subject populations of Byzantine Greeks, Armenians, Jews and Assyrians and many more, who were allowed a certain amount of autonomy under the millet, a separate court of law imposed by the Sultans as a way of governing the different religious populations, and whose distinctive cultures enriched that of the Ottoman state. ${ }^{2}$ Under this system, Christians and Jews, for example, were considered religious minorities and second-class citizens. They were subjected to elevated taxation, endured several forms of discrimination and were excluded from the Ottoman ruling elite, but in return they were granted autonomy within their own religious communities. ${ }^{3}$ Cultural objects created by Armenians in the Ottoman Empire are a case in point and the focus of this thesis. In his recent lecture on the context of the Armenian Genocide and cultural destruction at The Centre for Holocaust and Genocide Studies (CHGS) at the University of Minnesota, writer, poet and academic Dr. Peter

\footnotetext{
${ }^{2}$ Bruce Masters, Christians and Jews in the Ottoman Arab World: The Roots of Sectarianism (Cambridge: Cambridge University Press, 2001), 61-62.

${ }^{3}$ William Cleveland, A History of the Modern Middle East (Boulder: Westview Press, 2013), 45-46.
} 
Balakian stated that "[In the museum world], there is a lot of appropriation of minority cultures, historic identities and histories." Balakian called for specialists in the field to revise and revisit minority histories that have not been properly recognized, particularly in Middle Eastern or Ottoman contexts. ${ }^{4} \mathrm{He}$ explained that minority groups like the Kurds, Greeks and Armenians from the region are not being properly located on the map or wall exhibit in museums: their cultural accomplishments are labeled and attributed as simply "Ottoman." Such mislabelling diminishes and blurs the diverse contributions made by the Ottoman Empire's ethnic communities. Without knowledge of these contributions, we cannot get the full picture of the distinct photographic histories and traditions.

Using a selection of photographs currently housed in the New York Public Library's Photography Collection, this thesis aims to respond to Balakian's call by revisiting a selection of photographs created in the late Ottoman Empire. As noted, this thesis is structured around two case studies involving the works of ethnically Armenian photographer Gabriel Lekegian and Syrian-Armenian father-son duo Pascal Sébah and Jean Pascal Sébah in order to both expand awareness of misattributed or misappropriated catalogue records and to award a deeper recognition of ethnic minorities' contribution to photographic traditions and practices of the Ottoman Empire.

The thesis begins with a literature survey followed by a brief outline of the history of Armenian photographic practices in the late Ottoman Empire. The two case studies follow. They include biographical information pertaining to the photographer's lives and careers, a description of the NYPL holdings and an analysis of some of the issues present in their current catalogue records.

\footnotetext{
${ }^{4}$ Peter Balakian: The Armenian Genocide and Cultural Destruction. Performed by Peter Balakian. The Center for Holocaust and Genocide Studies. June 1, 2016. Accessed April 24, 2017.
} 


\section{Literature Survey}

The literature analyzed in the three following sections provided me with the necessary historical and theoretical context in order to address my thesis subject. First, the texts concerning early photography in the Ottoman Empire and the Middle East reveal that despite the fact that indigenous photographic traditions are beginning to be recognized, the contributions of ethnic minorities are still absent from mainstream histories of early photography. Second, the literature surrounding the Ottoman-Armenian photographic tradition acknowledges the legacy of Armenian photographers within Ottoman lands. Finally, the third section introduces a selection of articles which reveal modern-day Turkey's reluctance to recognize the cultural contributions made by ethnic and religious minorities from its Ottoman past.

\subsection{Early Photography in the Ottoman Empire and the Middle East:}

Photography historian and chief curator of photography at the Israel Museum in Jerusalem, Nissan Perez's book Focus East: Early Photography in the Near East (1839-1885) (1988) is a proficient starting point for studies of early photography in the Middle East. The book is divided into two parts. The first contains a series of essays organized by topic, including a brief history of relevant political events in the Middle East during this period and a description of predominant Western attitudes towards the region, and a portrayal of Orientalism and art, in particular the influence photography had on Orientalist paintings. Although the book is now somewhat dated, Perez's commentary provides a good overview of the subject. While Perez dedicates a small section to the emergence of local photographers in the Middle East, his focus 
remains on the works produced by resident or visiting European photographers. The book's second part, a biographical and alphabetical directory of photographers working in the Middle East, is particularly valuable as it contains images by, and information on, more than 250 photographers, most of whom remain unknown, including Gabriel Lekegian and the betterknown Sébah family. Despite, the heavy focus on European photographers, the index is comprehensive and the bibliography is useful as a quick reference.

Photography's Orientalism: New Essays on Colonial Representation (2013), edited by scholars Ali Behdad and Luke Gartlan, offers an overview of the works of European and nonEuropean photographers active in the Middle East. Building upon prior scholarship, the book includes eleven essays that explore the relationship between art and politics by considering the connection between the European presence in the Middle East and aesthetic representations produced by traveling and local photographers. ${ }^{5}$ While three of the essays in particular address instances of resistance to Orientalist tendencies under the Ottoman Empire, as a whole, the essays are imbalanced in their general dependence on contemporary European sources. Texts and accounts by non-European photographers and correspondents who record their reception to and uses of photography are ultimately lacking and would have benefited the book's overall agenda, which aims to address the field's lack of "in-depth cultural study" of photography from the region. ${ }^{6}$ Additionally, while European artistic traditions including painting and literature are mentioned, there is no consideration of pre-existing indigenous artistic traditions and the role that these might have played in the development of local photographic practices. These absences are not unique to Photography's Orientalism and echo continued gaps within the field, calling for alternative directions that future scholarship may take to give accuracy and agency to local

\footnotetext{
${ }^{5}$ Ali Behdad and Luke Gartlan, eds. Photography's Orientalism: New Essays on Colonial Representation (Los Angeles: Getty Research Institute, 2013), 2.

${ }^{6}$ Ibid.
} 
perceptions of the medium in order to help create a more comprehensive knowledge and analysis of photographic histories in the Middle East.

Scholar of Arab studies Stephen Sheehi's The Arab Imago: A Social History of Portrait Photography, 1860-1910 (2016), a social history of indigenous photography in both Ottoman and Arab worlds, is a model for the "alternative" directions that Photography's Orientalism calls for. Sheehi offers a clear counter narrative of the history of Ottoman and Arab photography by "bypassing photography's history of service to the "colonisateurs" in favour of interrogating the history of "native" photography of the late Ottoman and Arab world." 7 By focusing primarily on studio portraits by Arab and Armenian photographers in Ottoman Egypt, Lebanon, and Palestine, Sheehi shows that while Orientalist approaches offer some insight into the photographic culture of the Middle East, indigenous minority perspectives remain fundamentally absent. Composed of two parts, "Histories and Practice" and "Case Studies and Theory," The Arab Imago provides the field of Middle Eastern photography with an introduction to lesser-known indigenous photographic practitioners, texts on photography and photography studios. In doing so, Sheehi uncovers the history, ideology and social relations of indigenous photographic practices and sets forth a new methodology that shows how a consideration of indigenous photography can enlighten the "nature of photography" in the Ottoman world. ${ }^{8}$ While traditional art-historical approaches have a long way to go before the spotlight is shifted from the foreign to the indigenous photographer, Sheehi's contribution is valuable to the emerging stage of this developing scholarship. Overall, The Arab Imago succeeds in its attempt to "deprovincialize" the history of indigenous photography of the Ottoman world from European master narratives. ${ }^{9}$

\footnotetext{
${ }^{7}$ Sheehi, The Arab Imago, xxi.

${ }^{8}$ Ibid, xxii.

${ }^{9}$ Ibid, 4.
} 
Turkish historian Engine Özendes’ Photography in the Ottoman Empire 1839-1919 (1987) is an account of the factors affecting the development of photography as well as the development of photographic themes in the Ottoman Empire. She also includes a map of the Ottoman Empire tracing the studios of both resident European and local photographers. Özendes has also done extensive research on the Ottoman-Armenian studio of the Abdullah Frères in Abdullah Frères, Ottoman Court Photographers (1998) and on the Sébah family in From Sébah \& Joailler to Foto Sabah: Orientalism in Photography (1999). Both books provide an account of the lives and times of these photographers. Most importantly, Özendes is one of the first historians of photography to discover that the Sébah \& Joaillier studio was in fact not associated with Pascal Sébah, but was rather a partnership forged between his son Jean Pascal Sébah and French photographer Policarpe Joailler in 1888, two years after Pascal Sébah's death in 1886. From Sébah \& Joailler to Foto Sabah (sic) also provides valuable information regarding the Sébah family tree which Özendes was able to find through accessing birth and funeral records in Istanbul's Catholic churches. Her research shows that Pascal Sébah was born to a Syrian Catholic father and an Armenian mother. She also discovered that Pascal Sébah married an Armenian woman.

Finally, it is worth mentioning scholars Markus Ritter and Staci Gem Scheiwiller's forthcoming book The Indigenous Lens: Early Photography in the Near and Middle East (published by Walter De Gruyter Inc, September 2017) which aims to address issues surrounding "the regional histories of photography, local photographers, specific themes and practices, and historical collections in Iran, the Ottoman Empire and the Arab lands," ${ }^{10}$ with a particular focus on indigenous perspectives. Following in the footsteps of Sheehi, their book is another attempt to

\footnotetext{
${ }^{10}$ Markus Ritter and Staci Gem Scheiwiller, eds., The Indigenous Lens Early Photography in the Near and Middle East (Berlin: Walter De Gruyter Inc, forthcoming).
} 
fill the current gap in and demand for scholarship on indigenous photographic practices in the Middle East.

\subsection{The Ottoman-Armenian Photographic Tradition:}

The most thorough account of Armenian photographic practices was written in 1981 by scholar Dickinson Jenkins Miller. His MA thesis titled, “The Craftsman's Art: Armenians and the Growth of Photography in the Near East (1856-1981)" (MA in Middle Eastern Studies, American University of Beirut, 1981) remains one of the few studies in English that makes use of Armenian sources. Miller takes an historical approach, assembling some of the disparate facts already published to suggest that Armenians held an "ethnic monopoly" in the field of photography in the Middle East. He supplements this material with primary Armenian sources gathered during semi-structured interviews he conducted in Beirut, Lebanon from 1980-81. Over the span of five chapters, Miller introduces some of the early Armenian practitioners, provides a description of the photographic methods used and the commercial entities that were founded as well as some of the recent 1981 developments in the Armenian Diaspora. Miller also provides thorough footnotes and three appendices including a detailed list of names and addresses of early Armenian photographers and the masters from whom they learned their photographic skills, all of which serves as an excellent resource.

Photography collector and author Badr El-Hage has also written exclusively on Armenian photographers in the Middle East. In his essay, "The Armenian Pioneers of Middle Eastern Photography” (2007) for the Institute for Palestine Studies, El-Hage emphasizes the distinct circumstances (puritanical, political, economic, cultural and scientific) that allowed the 
Armenian community to monopolize photography production throughout the Eastern regions of the Ottoman Empire. This essay is certainly an important research tool for understanding the history of Ottoman-Armenian photographic production; however, the dominating presence of Istanbul (Constantinople) overshadows our perception of Ottoman-Armenian photography. While Istanbul certainly played an important role as the epicenter for Armenians and their studios, this perspective does not consider the importance of photographic production in other provinces of the Ottoman Empire. Furthermore, the essay is relatively short and does not include a bibliography, which limits the amount of analysis or comparison with other sources.

For a more in-depth analysis on provincial Ottoman-Armenian photography, Dr. David Low's "Photography and the Empty Landscape: Excavating the Ottoman Armenian Image World" (2015) which builds on his PhD thesis Framing the Armenian Genocide: Photography and the Revisualization of the Ottoman Empire, 1879-1923 (2015) confronts "history's failure to consider the provincial photography that constituted the bulk of Ottoman Armenian image production." ${ }^{11}$ Low's study on provincial photographers in Ottoman Armenia provides a conscious stepping away from the dominance of Istanbul-centric narratives and an introduction to provincial life through the photographic lens of Ottoman-Armenian actors in Kharpert. His work also concerns itself with photography's important role in maintaining solidarity within the Armenian community during times of mass migration and massacre. While Low addresses historical imbalances in Ottoman photographic history and offers possible remedies, he cannot clearly explain why its Armenian actors have not been represented well, something that needs to be addressed in order to shift these perceptions. As a whole, Low's work is important in

\footnotetext{
${ }^{11}$ David Low, "Photography and the Empty Landscape: Excavating the Ottoman Armenian Image World," Études arméniennes contemporaines 6 (2015) :3, accessed March 1, 2017. https://eac.revues.org/859
} 
considering the role of provincial Armenian photography and serves as a model for incorporating previously silenced voices into Ottoman photographic culture.

From a more personal perspective, professor and scholar, Dr. Armen Marsoobian has produced an exhaustive work of research titled Fragments of a Lost Homeland: Remembering Armenia (2015). Depending heavily on primary source materials including memoirs, letters and photographs, Marsoobian traces his family's history and survival by recounting the story of his ethnic Armenian ancestors, the Dildilians, who ran a successful photography business in Anatolia, the westernmost protudion of Asia, which makes up the majority of modern-day Turkey, from 1888 until their forced expulsion during the Turkish War of Independence in 19211922. Despite the importance of the Dildilian Studio to the government, the family was forced to convert to Islam in order to avoid deportation. Demonstrated through his book and a series of international photography exhibitions, ${ }^{12}$ Marsoobian acknowledges the notion of collective memory as a way to encourage modern Turkish society and government to take responsibility for their nation's past. Although the book does not cover the complete history of the OttomanArmenian photographic tradition, its account of the Dildilian family and their story provides valuable context for the political strife Armenians faced during the late Ottoman period and demonstrates how photography played a role not only in their survival but as a way of recovering a lost past.

\subsection{Cultural Misattribution in Ottoman Contexts:}

Author and director of publications for The Armenian Mirror-Spectator, Edmond Y. Azadian's article "Looters or Landlords?" (2012) published in The Armenian Mirror-Spectator, outlines a

\footnotetext{
${ }^{12}$ Four major photography exhibitions have taken place in Istanbul, Marsovan, Diyarbakir and Ankara.
} 
number of historical precedents for cases of cultural misattribution in the present government of Turkey. At issue are many artifacts created by ethnic minorities of the Ottoman Empire, such as the Armenians, Assyrians, Greeks and other nationalities. From the disputing of cultural treasures in Western museums, to the mislabelling of Armenian artifacts in Turkish institutions, Azadian demonstrates how the government of Turkey has been selectively using its Ottoman heritage to reclaim objects of cultural heritage that, while created or found in what were once Ottoman-occupied lands, are not necessarily of "Turkish" origin. This claim asserts that any cultural artifact found on Turkish soil, whether created by Armenians, Assyrians or Greeks, is "Turkish," part of Turkish history and culture - thus denying the ethnic diversity of the Ottoman Empire. While Turkey has had many recent successes in retrieving disputed artifacts from abroad, Azadian insists that, "Since Turkey selectively wishes to use its Ottoman heritage, than it has to recognize the Ottoman Genocide against the Armenians, which not only destroyed millions of human lives, but also the cultural heritage of that subject nation."13

In the same vein, Volkmar Gantzhom author of The Christian Oriental Carpet (1991) examines the history of the origins and development of Oriental carpets. With the use of historical and bibliographical material, the author aims to create the awareness that all the ornamental patterns and compositional motifs of Oriental carpets woven by Christian Armenians, stem from Armenian heritage and identity, contrary to their association with Islamic culture and history. By shedding light on the distinct characteristics produced by the ideological and artistic identity of Armenian-produced carpets, Gantzhom attempts to repair the injustice done to the Armenians who have "been robbed of their art, the authorship for which has been attributed to

\footnotetext{
${ }^{13}$ Edmond Y. Azadian, “Looters or Landlords?” The Armenian Mirror-Spectator, October 2012, accessed April 24, 2017, http://www.mirrorspectator.com/2012/10/03/looters-or-landlords/
} 
the conquerors, either due to ignorance of the facts involved, or the manipulation of these facts." $" 14$

Finally, in the context of Ottoman art histories, Vazken Davidian, doctoral candidate in the history of art at Birbeck University of London, attempts to "repopulate the Ottoman art historical landscape with some of its Ottoman-Armenian actors". ${ }^{15}$ His paper titled "Reframing Ottoman Art Histories: Bringing Silenced Voices Back into the Picture,” (2015) published in Études arméniennes contemporaines, insists that while the Ottoman Armenians played a major role in shaping all aspects of Ottoman visual culture, there exists a resistance to discussing and considering their contributions, resulting in misrepresentations and exclusions within Ottoman art history contexts. By reintegrating Ottoman-Armenian artists within existing Ottoman and post-Ottoman art historiography, Davidian challenges nationalistic art history production to call for new revisionist Ottoman art histories.

\footnotetext{
${ }^{14}$ Volkmar Gantzhom, introduction to The Christian Oriental Carpet (Cologne: Taschen, 1991), 12.

${ }^{15}$ Vazken Davidian, "Reframing Ottoman Art Histories: Bringing Silenced Voices Back into the Picture" Études armeniennes contemporaires 6 (2015): 7, accessed March 1, 2017. https://eac.revues.org/875
} 


\section{The Historical Context}

In the Ottoman Empire the discovery of photography was announced on October 28th 1839, in the government newspaper Takvim-i Vekayi, published in Istanbul in Turkish, Arabic, French, Greek and Armenian (reflecting Istanbul's diverse ethnic population). ${ }^{16}$ After its initial announcement, photography in the Ottoman Empire was mainly carried out by photographers and travelers from Europe who then brought their work back with them. ${ }^{17}$ These photographers were primarily interested in documenting archaeological monuments and structures; however as Western travelers became more familiar with the region, they also began to photograph local people, street scenes and markets. The increased exposure and popularity of Ottoman subjects resulted in the emergence of resident European studios in the major cities of the Ottoman Empire. ${ }^{18}$ It was only by the mid-1850s that the first few local photographers began to appear, particularly in Istanbul and mainly along Grand Rue de Pera, home to the major European embassies, traders and hotels catering to European travelers. ${ }^{19}$

While we are more than familiar with resident European photographers such as Francis Frith and Auguste Salzmann, both of whom have their long established place in the history of photography in the Middle East, local or indigenous photographic practices from the region are just beginning to be recognized and acknowledged. The distance from Europe and the time it took for new inventions and materials to arrive and gain acceptance in the area limited the possibilities for local photographers. But even more restrictive than physical distance were the religious taboos of a traditional Islamic society. In particular the Second Commandment, which

\footnotetext{
${ }^{16}$ John Hannavy ed., Encyclopedia of Nineteenth-Century Photography (New York: Routledge, 2008), 1034.

${ }^{17}$ Nissan Perez, Focus East: Early Photography in the Near East 1839-1885 (Jerusalem: The Domino Press, Ltd, 1988), 76.

${ }^{18}$ Engin Özendes, Photography in the Ottoman Empire, 1839-1919 (Istanbul: Iletisim Publications, 1995$), 44$.

19 Özendes Photography in the Ottoman Empire, 35.
} 
prohibited the making of "graven images," offered little chance for the acceptance of

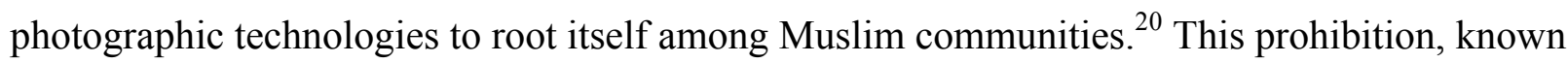
as aniconism, strictures against the creating images that represent and worship living beings. ${ }^{21}$ While the most absolute exclusion is of images of God in Islam and depictions of Muhammad, the depiction of all humans and animals is also discouraged. It appears, however, that photographs were allowed to be produced and circulated in the Ottoman Empire - the Ottoman Sultan Abdülhamid II engaged obsessively in a photographic census of his domains - so long as they were taken by non-Muslim subjects. ${ }^{22}$

The first local photographers to open shop were therefore minority Christians who were not bound by such restrictions. The initial Armenian encounter with photography is generally thought to be in $1856 .^{23}$ That year Vichen Abdullah began working for a German chemist named Rabach who owned a newly opened studio at 417 Grande Rue de Pera in Istanbul. Vichen was the eldest of what would become the leading Armenian photographic firm, the Abdullah Frères (active 1858-1899) who would garner a reputation for their work as court photographers of Ottoman Sultan Abdul-Aziz. ${ }^{24}$

\subsection{The Armenians and Armenian Photographers in the Ottoman Empire:}

\footnotetext{
${ }^{20}$ Nissan Perez, Focus East: Early Photography in the Near East 1839-1885 (Jerusalem: The Domino Press, Ltd, 1988), 76.

21 "Figural Representation in Islamic Art," The Metropolitan Museum of Art, accessed August 13, 2017, http://www.metmuseum.org/toah/hd/figs/hd_figs.htm

22 Edhem Eldem, "Powerful Images: The Dissemination and Impact of Photography in the Ottoman Empire, 18701914," in Camera Ottomana: Photography and Modernity in the Ottoman Empire, 1840-1914, ed. Çelik, Zeynep and Edhem Eldem (Istanbul: Koc University, 2015), 112.

${ }^{23}$ Dickinson Jenkins Miller, The Craftsman's Art: Armenians and the Growth of Photography in the Near East (1856-1981)" (M.A. thesis, American University of Beirut, 1981), 14.

${ }^{24}$ Ibid.
} 
For the Ottoman Empire in general and the Armenians in particular the nineteenth century was a period of extraordinary social, political and economic activity. There were Armenian communities throughout the Ottoman Empire, and Armenian subjects, who were part of the second largest minority community in the Empire, had important roles to play. Similar to the Greek Orthodox and Jewish minorities of the Ottoman Empire, the Armenians constituted a distinct millet, led by the Armenian Patriarch of Constantinople (present day Istanbul). ${ }^{25}$ Armenians, in particular, had their own distinct confessional traditions, variously worshiping in Armenian Apostolic, Armenian Catholic and Armenian Protestant churches. They governed hundreds of Armenian schools and hospitals and published and edited Armenian newspapers. There were Armenian physicians serving at the palace or as government doctors. From the seventeenth century onwards, the Armenian Duzian family had run the Ottoman mint. The Armenian language, traditionally a liturgical medium, was also expanding during this period resulting in a new vernacular soon accessible to an increasingly large number of educated Armenians. ${ }^{26}$ The French influence was especially pertinent and many French publications were translated into Armenian. These publications were known to announce the latest developments in technical fields such as chalcography (copper plate engravings used for printmaking) and xylography (woodcuts or wood engravings used in printmaking). As Dickinson Jenkins Miller suggests, "These efforts greatly facilitated the spread of new scientific knowledge and similar publications would be one of the vehicles through which photography entered into the occupational domain of the Armenian community."27

There were a number of reasons why the Armenian community were fit to adapt to photographic techniques and processes. Armenians were skilled artists and craftsmen involved in

\footnotetext{
${ }^{25}$ İlber Ortayl1, Son Imparatorluk Osmanlı [The Last Empire: Ottoman Empire] (Istanbul: Timaş Press, 2006), 87-89.

${ }^{26}$ Miller, The Craftsman's Art, 11.

${ }^{27}$ Ibid.
} 
both commercial and industrial activities, famed particularly as pharmacists and chemists. But it was as goldsmiths, that they were undoubtedly the most renowned, and had been since the early 1700s. The work of Armenian craftsmen in both chemistry and metallurgy familiarized the community with materials whose qualities bore substantial resemblance to the metals and chemicals employed by the daguerreotype, the first commercially successful photographic process in the history of photography. The daguerreotype, in particular, merits our attention for in some ways its process was additionally akin to that employed in the field of printing which Armenian also dominated during the nineteenth century. ${ }^{28}$ Armenians were also traditionally trained in miniature painting. For instance, both Kevork and Vichen Abdullah of the Abdullah Frères were skilled miniature painters in their own right prior to their first contact with the photographic medium. ${ }^{29}$ Their talent proved to be a great asset to their photographic work and they are said to have operated a gallery as well as a photographic studio. ${ }^{30}$ The variety of professions, which required a particular artistic and technical awareness, were historical antecedents to Armenian involvement in the field of photography, informing the adaptation of photographic techniques and processes such as hand-colouring and retouching.

Their abundance of artisan-craft knowledge was further complemented by the class structure of the Ottoman Empire, because, as noted above, Muslims were essentially prohibited from practicing any commercial profession. In general, the majority Muslim population had careers that were exclusively reserved to them such as positions in the military, the civil service or the ulema (scholars expert in Islamic sacred law and theology). ${ }^{31}$ This division of labour opened up or forced non-Muslim citizens of the Ottoman Empire into non-governmental roles,

\footnotetext{
${ }^{28}$ Ibid, 44.

${ }^{29}$ Ibid, 39.

${ }^{30}$ Ibid, 75.

${ }^{31}$ Özendes, 49.
} 
among which were trade and the arts, positions that required some sort of familiarity with Western culture and Western networks of import/export. Their minority status thus left Armenians free to develop their commercial practices through close family networks, typically multi-fraternal associations. As with other ethnic minority groups the Armenians passed down their studios to future generations facilitating the abundance of resources within their own communities. $^{32}$ The result was a growing Armenian photographic community that spread throughout the Ottoman Empire and the Middle East.

Armenian involvement in photography came to an slight halt during World War I when the Armenian millet fell victim to the violent beginnings of the modern Turkish state. ${ }^{33}$ While some Armenian photographers continued to work in certain cities in the Ottoman Empire, over a million Armenians who resided in Anatolia and historical Armenia were systematically deported and often killed or left to die in what is known today as the Armenian Genocide. Although the Armenian Genocide is almost unanimously acknowledged as a historical fact by historians and genocide scholars, the government of Turkey continues to deny that there ever was a genocide, resulting in continued anguish and conflict between Turkey and Armenia, including the large Armenian diaspora. Those who were able to escape the massacres took refuge in neighbouring countries such as Syria, Iraq, and Egypt, while others migrated to Europe and North America. ${ }^{34}$ There they began to recreate what they had lost in their Ottoman homeland, while adapting to new economic conditions of extreme hardship. ${ }^{35}$ For the Armenians, the craft of photography was one of the means used to rebuild their lives as they relocated to new homes. While the

\footnotetext{
${ }^{32}$ Badr El-Hage, "The Armenian Pioneers of Middle Eastern Photography" Journal of Palestine Studies, 31 (2007), 26, accessed March 1, 2017, http://www.palestine-studies.org/sites/default/files/jqarticles/31_hage_1.pdf

${ }^{33}$ Miller, The Craftman's Art, 55.

${ }^{34}$ El-Hage, "The Armenian Pioneers of Middle Eastern Photography," 26.

${ }^{35}$ Miller, 55.
} 
forced migration of many Armenians meant starting from nothing, the knowledge and craft they had developed allowed them to rise in distinction in their new adopted communities, leading economic activity in various arenas throughout the Middle East and North America. ${ }^{36}$ Armenian-Canadian photographer Yousuf Karsh (1908 - 2002) who was born in Mardin, Ottoman Empire (present-day Turkey) and immigrated to Canada by way of Syria in 1924, is an example of such distinction. After assisting his uncle, Aziz George Nakash (1892 - 1976) who ran a successful photography studio in Montréal, Canada, Karsh further developed his skills from John H. Garo (1875 - 1929), the most prominent Armenian-American photographer at the time, in Boston who had immigrated to the United States in 1885, as the political stability of the Armenian community in the Ottoman Empire was beginning to weaken ${ }^{37}$ Today Karsh is best known for portraits of notable individuals and is widely recognized as one of the greatest portrait photographers of the $20^{\text {th }}$ in both Canadian photographic history and beyond.

The ethnic minority - in this case Armenian - backgrounds of Ottoman photographers played an important role in their photographic careers and traditions. Circumstantial evidence indicates that the Armenian community possessed a wealth of artisan-craft knowledge, including a proficiency in the knowledge of chemistry and types of picture making derived from miniature painting and printmaking processes of the nineteenth century. Their skills, along with their religious status as non-Muslim minorities, helped prepare these members of the Armenian community for their contribution to photographic practices. However, rarely are such ethnic distinctions noted in catalogue records. With the absence of such distinction, the role of nonMuslim indigenous minority groups, like the Armenians, remains unknown. Having an understanding of this background matters for curators, collectors, institutions and the art market,

\footnotetext{
${ }^{36}$ El-Hage, 26.

${ }^{37}$ Mehmed Ali, Yousuf Karsh \& John Garo: The Search for a Master's Legacy (Massachusetts: Benna Books, 2015), 2-5.
} 
because the value of photographs is not only dictated by what is depicted, but also by whom and how they were produced. The records for three Ottoman photographers: Gabriel Lekegian, Pascal Sébah and Jean Pascal Sébah, all of whom come from Armenian backgrounds and circumstances, in the New York Public Library’s Miriam and Ira D. Wallach Division of Art, Prints and Photographs are a case in point. 


\section{Case Study: Gabriel Lekegian}

For nearly three decades the Lekegian \& Co. studio held a prominent position in Cairo producing thousands of images depicting the daily life, nature and architecture of Egypt. Lekegian, whose first name is mentioned as Gabriel in some secondary sources, was born in 1853 . The Armenian Immigrant Project, a website which contains abstracts of primary source material for the study of Armenian immigration to North America through 1930, has a record of Lekegian arriving in Chicago in 1893 at the age of 40, presumably for the World's Columbian Exposition in Chicago. The record also indicates that he was travelling with his wife, Lucie who was 32 at the time and a child who was four years old. It is not exactly clear where Lekegian was born, however sources suggest that he was based in Istanbul as of $1880 .^{38}$

Known as the most important nineteenth century Armenian photographer in the Egyptian capital, ${ }^{39}$ Lekegian's initial appearance in Istanbul was as a painter, the student of the Italian expatriate artist, Salvatore Valeri. ${ }^{40}$ Working primarily in watercolours, Lekegian produced a series of figurative and genre studies in the style of his instructor. It is also known, thanks to the research conducted by Dickinson Jenkins Miller, that he married the sister of Maghak'ia Ormanian, the Patriarch of the Armenian Orthodox Church in Istanbul, one of the most distinguished intellectual and religious figures of the period. ${ }^{41}$ Miller suggests that Lekegian's own family must have been associated with upper elements of the traditional authority in the Armenian community for him to be married into such a family.

\footnotetext{
38 "Gabriel Lekegian," Lusadaran: Armenia Photography Foundation, accessed March 29, 2017, http://lusadaran.org/artists/gabriel-Lekegian/.

${ }^{39}$ Miller, The Craftsman's Art, 23.

40 "Gabriel Lekegian."

41 Miller, The Craftsman's Art, 25.
} 
It is not clear what exactly triggered Lekegian's move to Cairo or the exact date of his arrival there, although Miller has suggested that he established his studio in $1887 .{ }^{42}$ Nor are there any details about his switch from painting to photography. Perhaps recognizing the promising commercial prospects of photography and realizing the concentrated tourist traffic in Egypt after the construction of the Suez Canal, Lekegian made the decision to leave the already competitive scene in Istanbul forming his studio "Photographique Artistique G. Lekegian \& Cie.",33 Establishing his studio opposite Shepheard's Hotel in the heart of Cairo's European district, Lekegian positioned himself as an 'artistic' photographer, as his studio name suggests, distinguishing himself and his work from his mainly French or Greek competitors.

Upon the establishment of his studio, Lekegian immediately began to produce quantities of dry-plate negatives, carefully composed photographs that were popular with tourists and European residents of Cairo. Along with the depictions of famous views such as the Pyramids, the temples in Luxor and the Nile, Lekegian produced images drawn from the daily life of local peasantry, showing the complex, diverse and rapidly changing environment of Egypt at the time. This aspect of his work was particularly aimed at the art market, essentially catering to French and British Orientalist painters in need of visual references. ${ }^{44}$

As a businessman he was fully conscious of the tourist market demands and was prepared to satisfy them by producing exotic images of the East that ignited the imagination of his predominantly Western clientele, including images of nude women and studio set-ups suggesting a harem like setting. ${ }^{45}$ This type of imagery is balanced with more direct, observational photographs depicting the daily realities on the streets in both Islamic and Christian quarters of

\footnotetext{
${ }^{42}$ Ibid, 23.

43 "Gabriel Lekegian."

${ }^{44}$ Ibid.

${ }^{45}$ Examples of this type of imagery can be found at Lusadaran: Armenian Photography Foundation website: www.lusadaran.org.
} 
Egypt. ${ }^{46}$ As a result, Lekegian was prompted to participate in a number of international exhibitions, including the 1892 International Photography Exhibition in Paris and, as noted above, the 1893 World's Columbian Exposition in Chicago. ${ }^{47}$ In addition to providing pictures for the tourist market, Lekegian became closely tied to the ruling authorities as the "Photographer of the British Army of Occupation." He also became a favored photographer of the Egyptian royal family, many of whom had their portraits taken by him. ${ }^{48}$ This was not unique to Lekegian as many Armenian and Greek photographers were often commissioned by the royal families or Sultans to take their portraits. It is also worth noting that Lekegian's photographs have been used to illustrate books, two of which belong in the NYPL's Rare Books Collection: A.B. Guerville's 1905 New Egypt and S.H. Leeder's 1912: Veiled Mysteries of Egypt and the Religion of Islam.

The New York Public Library's Photography Collection ${ }^{49}$ contains ninety-one albumen prints and four silver gelatin prints by Gabriel Lekegian. It is unclear how these photographs arrived in the Library's Photography Collection. Nor is it clear whether they were produced by commission or simply purchased and brought back to North America by a wealthy traveler or collector. The Library records indicate the source of these photographs as unknown although the card catalogue indicates the date of their arrival in the New York Public Library as 1932. Prior to their coming

\footnotetext{
46 "Gabriel Lekegian."

${ }^{47}$ Julie K. Brown, Contesting Images: Photography and the World's Columbian Exposition (Arizona: University of Arizona Press, 1994), 110.

${ }^{48}$ Miller, "The Craftman's Art", 23

${ }^{49}$ The Photography Collection was created in 1980 when images from other New York Public Library departments and branches were culled together to form a new division that now comprises more than 500,000 photographs by 6,000 photographers.
} 
to the Photography Collection, the photographs belonged to both the Library's General Research Division and Arts \& Architecture Division.

The prints are titled, numbered and signed "Photogr. Art. G. Lekegian" or "Photogr. Artistique G. Lekegian.” The images portray street scenes, markets and mosques in the city of Cairo along with scenes of local residents engaging in daily labour activities in the countryside (fig. 5) and views of tourists climbing onto the pyramids (fig.6). Many views include work and animals (fig. 10) and show boats on the Nile River; one view shows a public inauguration ceremony. In addition, there are also five intimate portraits of locals, four of which were taken in front of what looks like a blank canvas in a studio setting (figs. 2, 3, 4).

Puzzled as to why Lekegian's nationality was described in the catalogue records as "French," I decided to refer to the Getty's Union List of Artist Names (ULAN) Database, which cultural institutions view as the standard for defining artists' nationalities as well as their birth/death dates. Getty's ULAN Database suggests that Lekegian was either an “Armenian or French photographer, active late $19^{\text {th }}$ century in France or Egypt;" however the preferred nationality for Lekegian according to the ULAN is "Armenian." ULAN, "Preferred Nationality" is "the nationality most commonly associated with the artist. Note that nationality is not a legalistic designation; it does not necessarily indicate citizenship or a particular nation, empire or city state," (Getty ULAN). If, based on Getty ULAN's guidelines, Lekegian was commonly associated with being "Armenian," then why was he catalogued as "French" in the NYPL records? No one at the library knew the answer. More puzzling still was the Getty Museum's own website which gave his nationality as French without offering any bibliography or sources to support this claim.

\footnotetext{
${ }^{50}$ Getty ULAN database includes a number of sources including the Canadian Centre for Architecture Database, Eastman House Database, Getty Vocabulary Program Rules.
} 
What is certainly clear is that Lekegian was not French. He never lived or worked in France, nor was there any evidence of him having been born in France or having French citizenship. Perhaps the mistake arises from the fact that he titled and signed all his prints in French - a common custom amongst nineteenth century Armenian businessmen who were generally Francophiles. French was the international language at the time, like English is today. The photographic studio name of the "Abdullah Frères" is another example of international Francization. It is also intereting to note that while the catalogue records at the NYPL and the Getty ULAN use the French spelling of Lekegian's name with acute accent marks (Lékégian), no accent marks are used on the photographs themselves. It seems that the addition of the accents was a deliberate choice made by the institutions in order to justify Lekegian's so called "French" heritage. While the French spelling has become somewhat of a standard for his name, I decided to use Lekegian's name without the accents, as it appears on his photographs.

As I've shown, Lekegian was a creator who was of ethnic Armenian descent and who spent the majority of his photographic career in Cairo, Egypt. Without this information, one would assume that he came to the Cairo as a French photographer or tourist interested in photographing views of Cairo to bring back to France. This would be a mistake. Without having insight to Lekegian's ethnic identity we cannot understand whether he and other locally-based photographers operated in ways that were different from their European counterparts. Nor can we analyse the role his early career as a painter played in his photography. Photographic traditions in France are usually acknowledged in the context of the history of photography and French photographers are defined by their national identities. Lekegian's photography should also have the right to be defined in the context of his cultural heritage. 


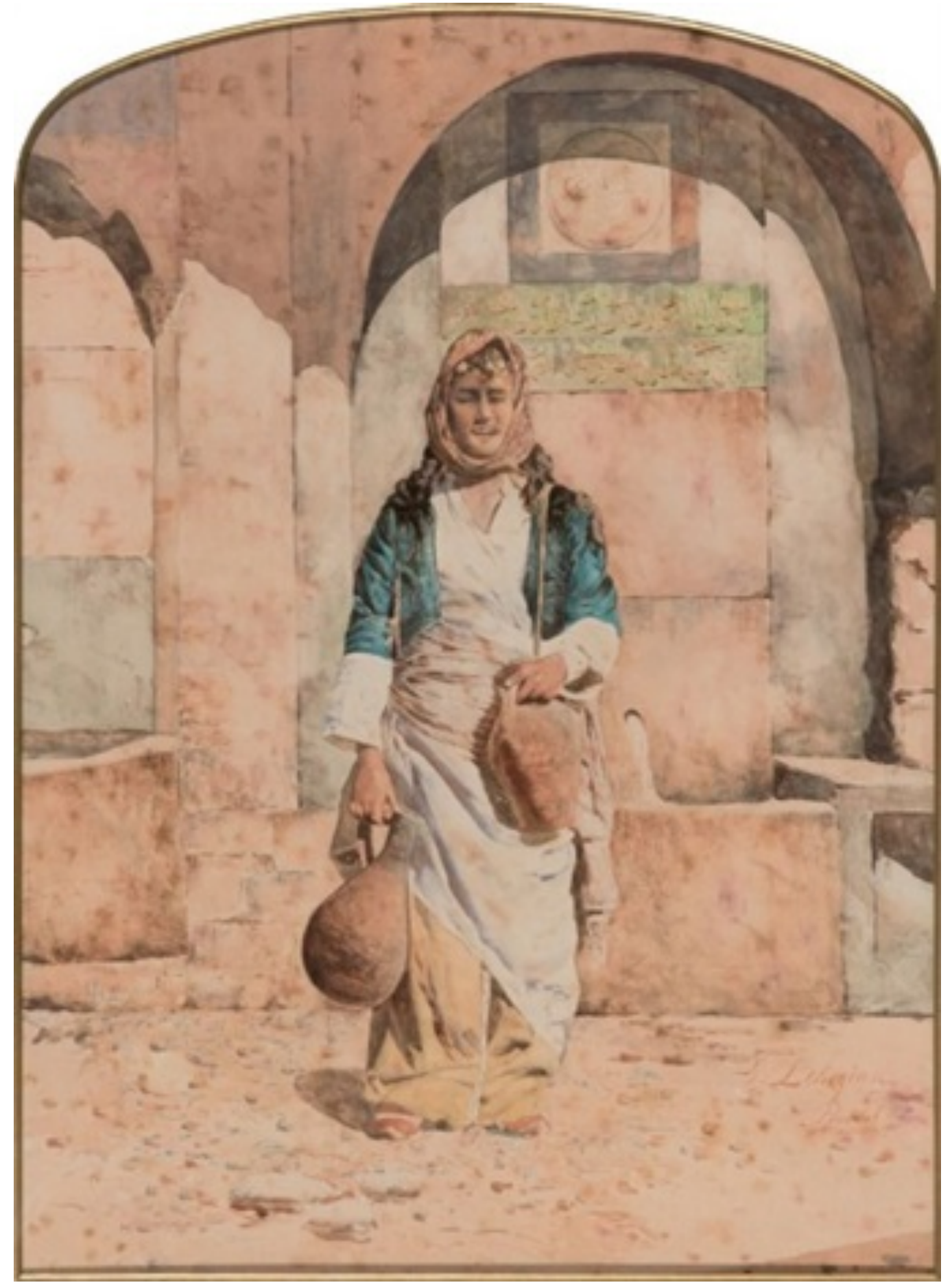

Figure 1. Gabriel Lekegian, Porteuse d'eau a Constantinople (c.1880)

Image courtesy of Artnet. (C) Gabriel Lekegian 


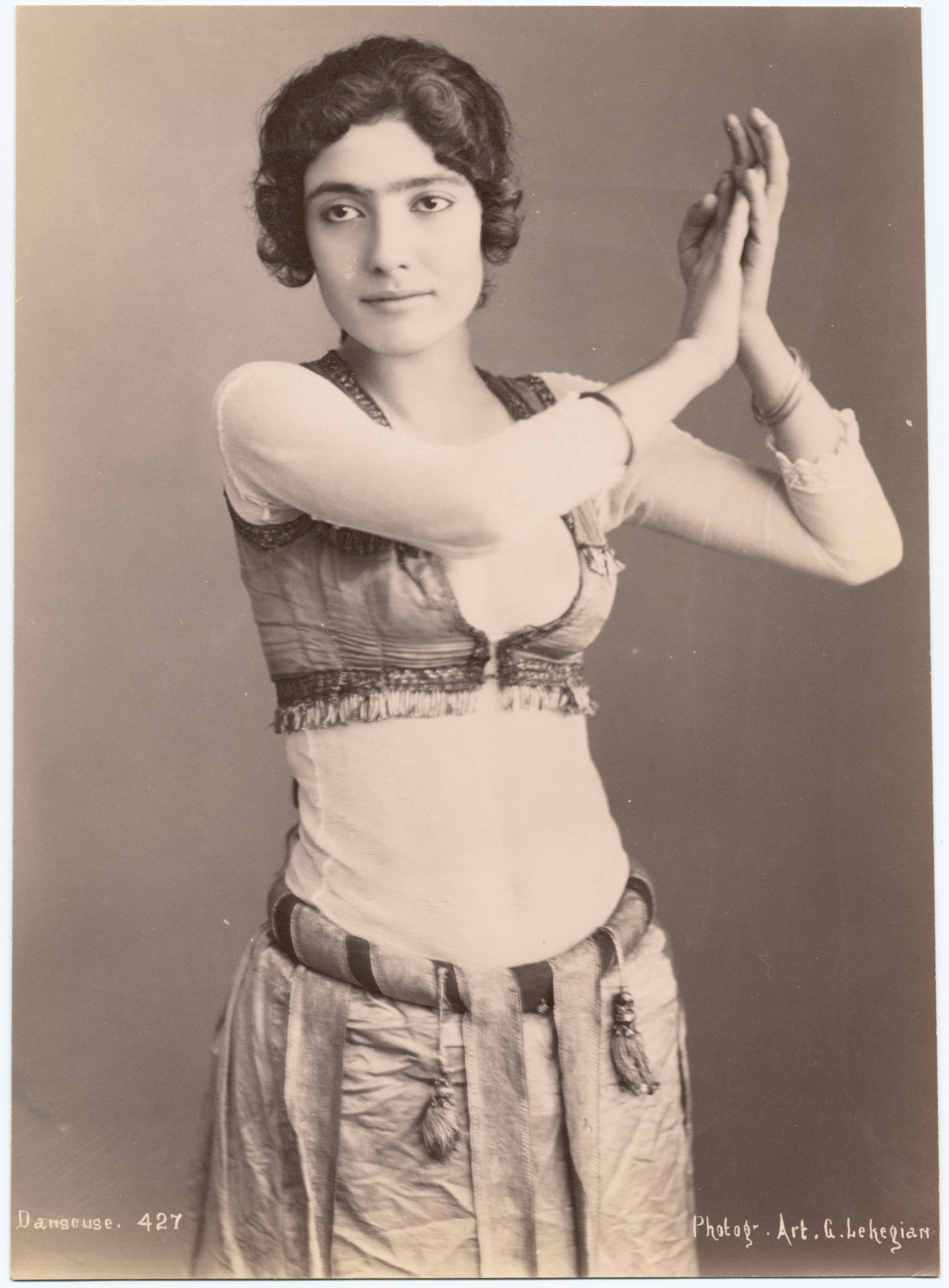

Figure 2. Gabriel Lekegian, Danseuse, 1887-1890

Image courtesy of the New York Public Library. Reproduced by permission of the New York Public Library. (C) Gabriel Lekegian 


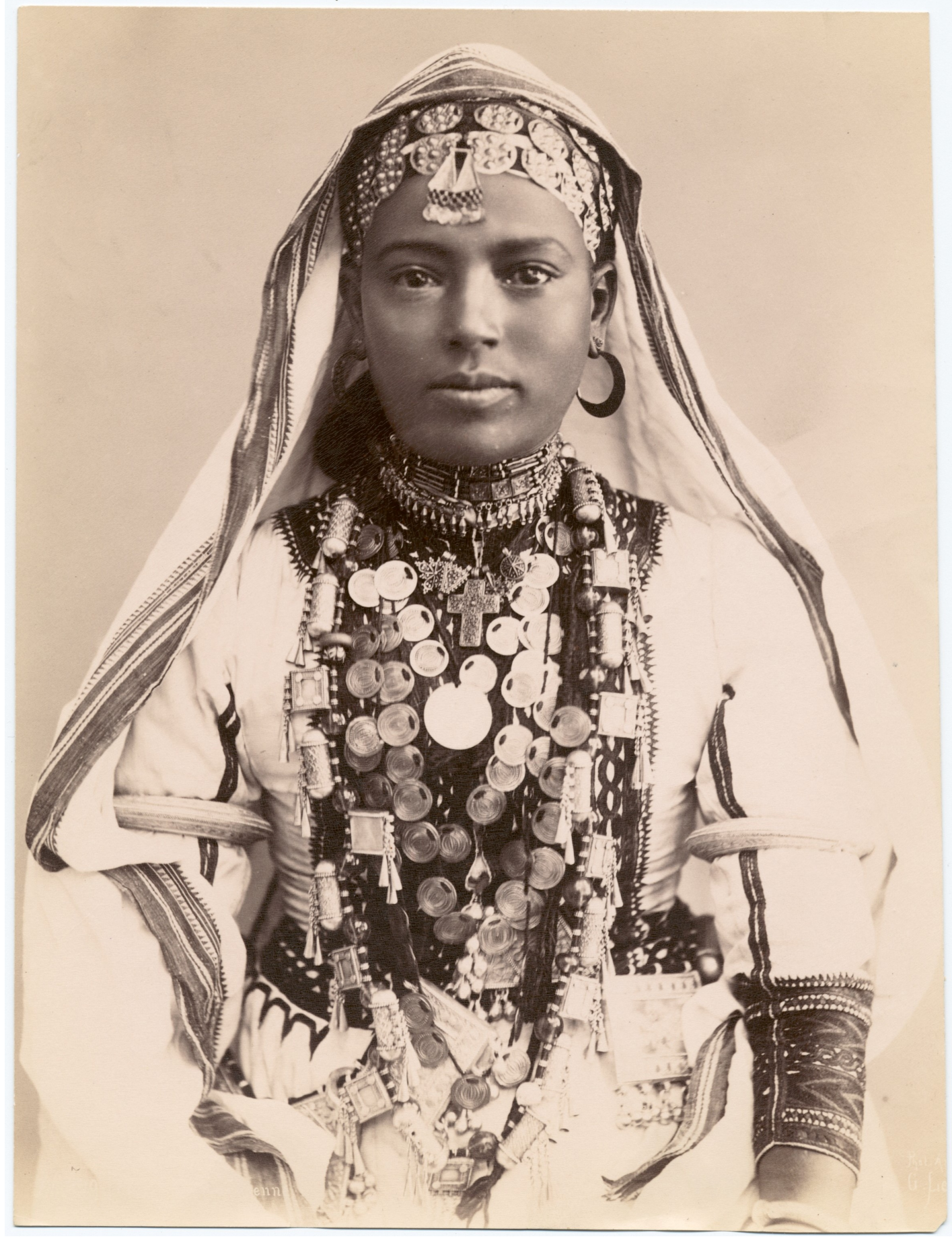

Figure 3. Gabriel Lekegian, [Girl in Ceremonial Dress], 1887-1890

Image courtesy of the New York Public Library. Reproduced by permission of the New York Public Library C Gabriel Lekegian 


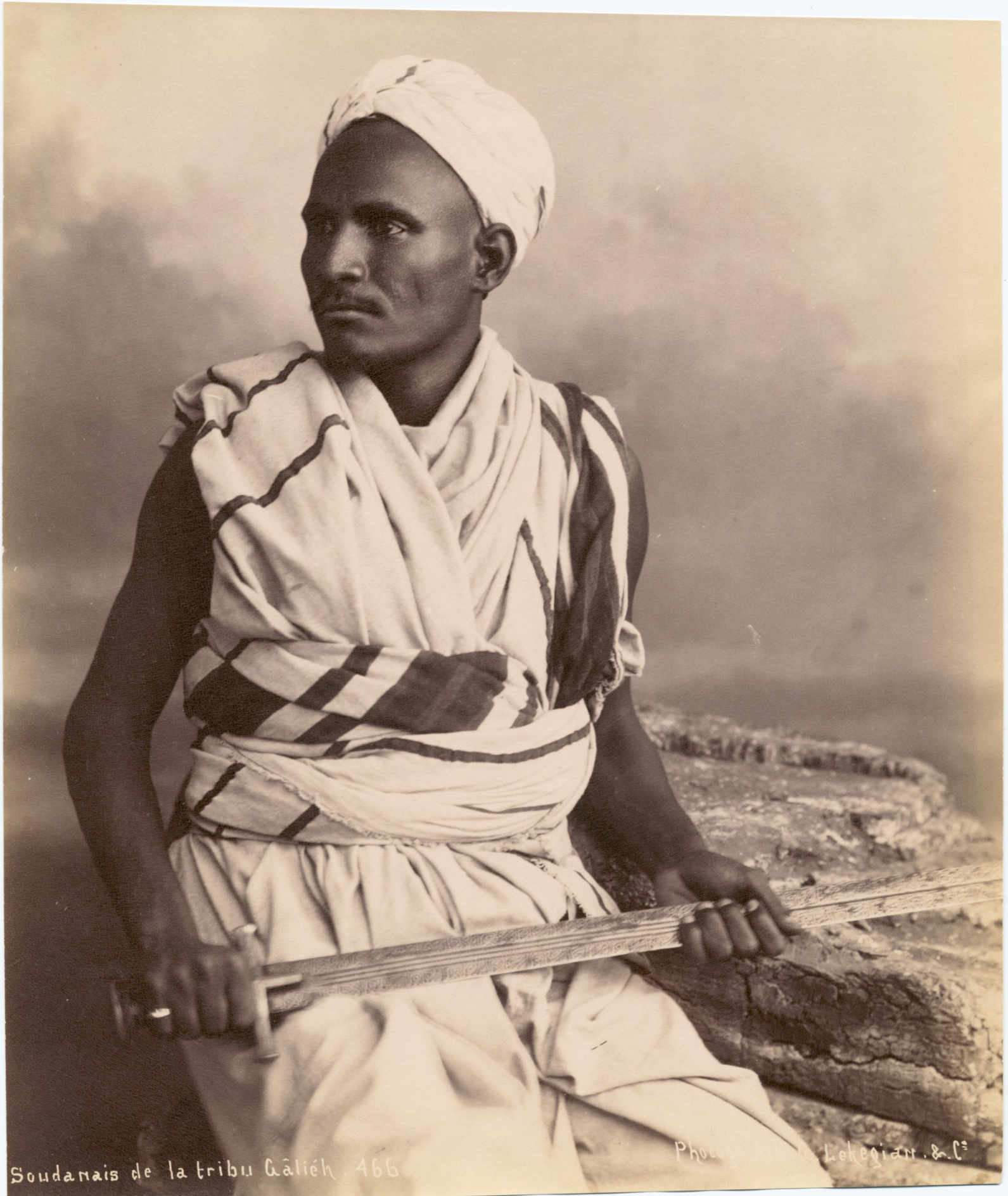

Figure 4. Gabriel Lekegian, Sudanais de la tribu Gâlièh, 1887-1890

Image courtesy of the New York Public Library. Reproduced by permission of the New York Public Library (C) Gabriel Lekegian 


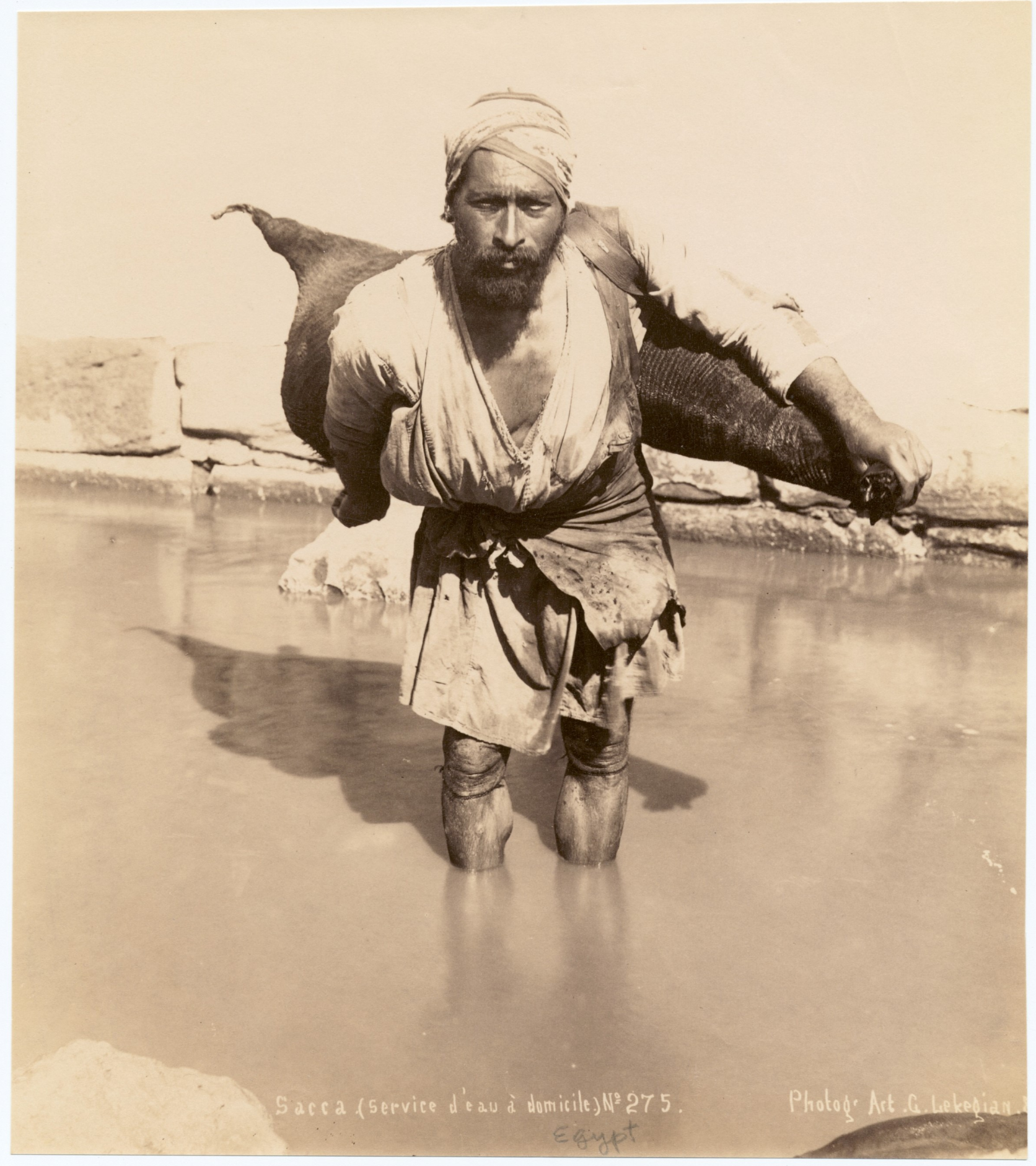

Figure 5. Gabriel Lekegian, Sacca (service d'eau à domicile), 1887-1890

Image courtesy of the New York Public Library. Reproduced by permission of the New York Public Library.C Gabriel Lekegian 


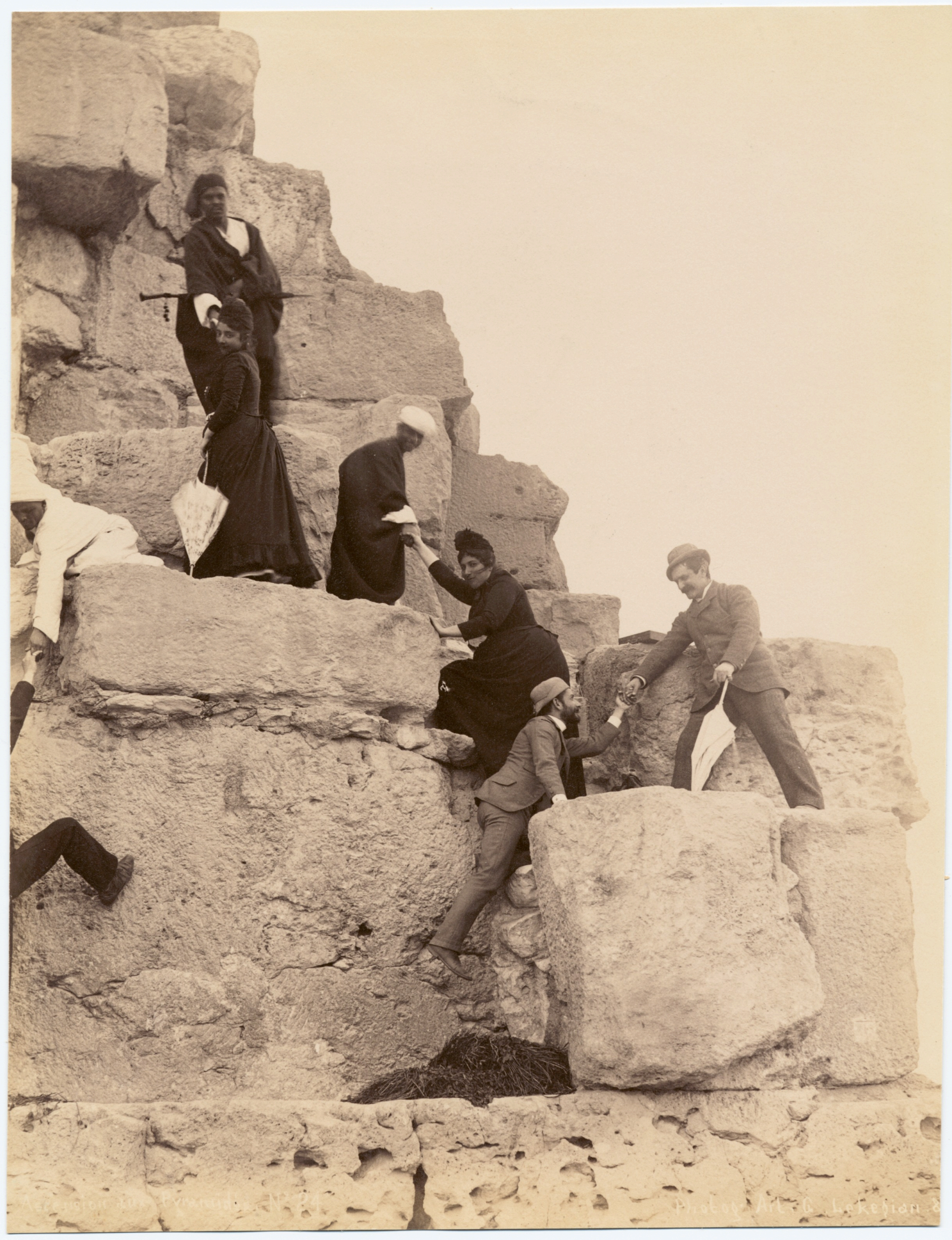

Figure 6. Gabriel Lekegian, Ascension aux Pyramides, 1887-1890

Image courtesy of the New York Public Library. Reproduced by permission of the New York Public Library. C Gabriel Lekegian 


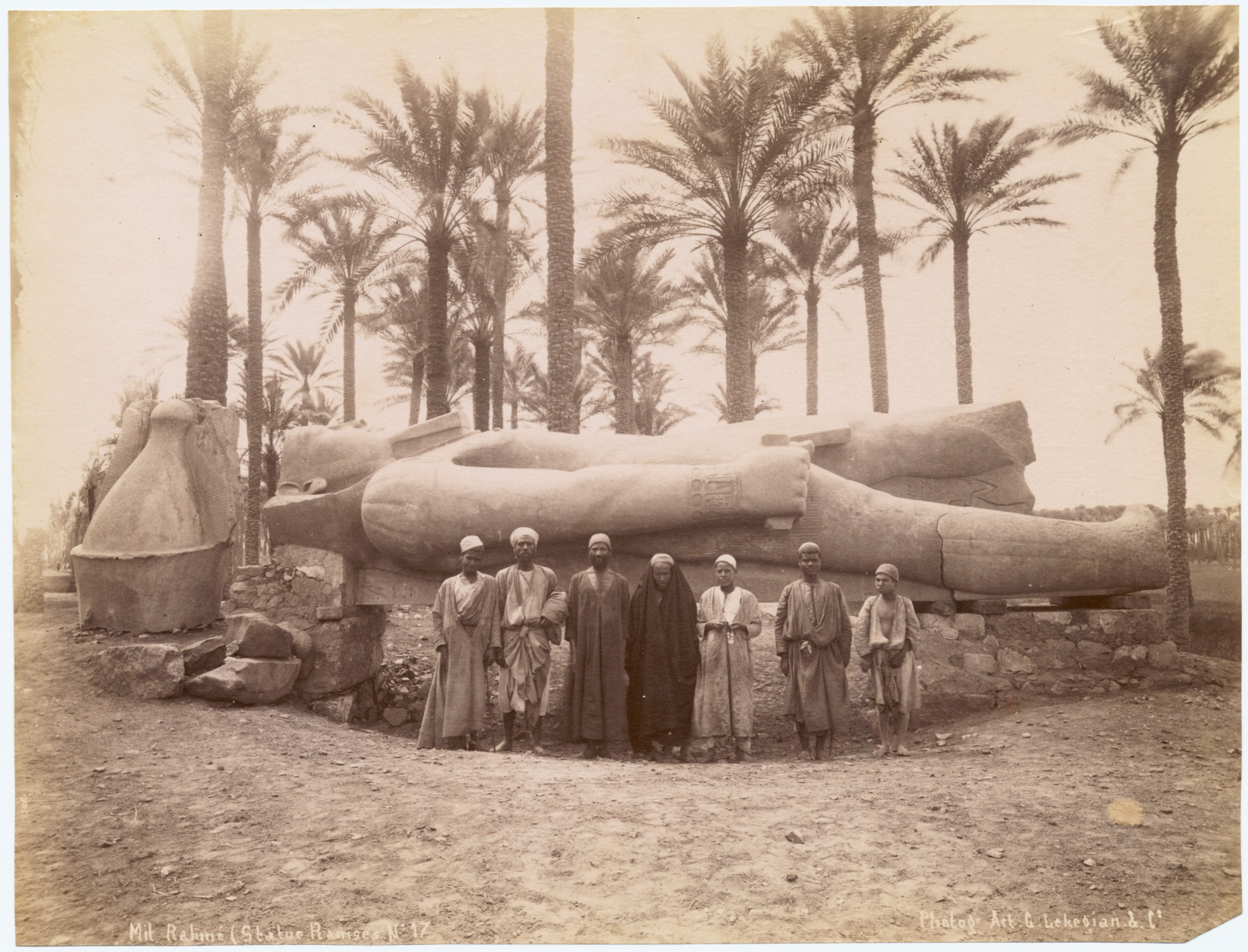

Figure 7. Gabriel Lekegian, Mit Rahiné (statue Ramses), 1887-1890

Image courtesy of the New York Public Library. Reproduced by permission of the New York Public Library. (C) Gabriel Lekegian 


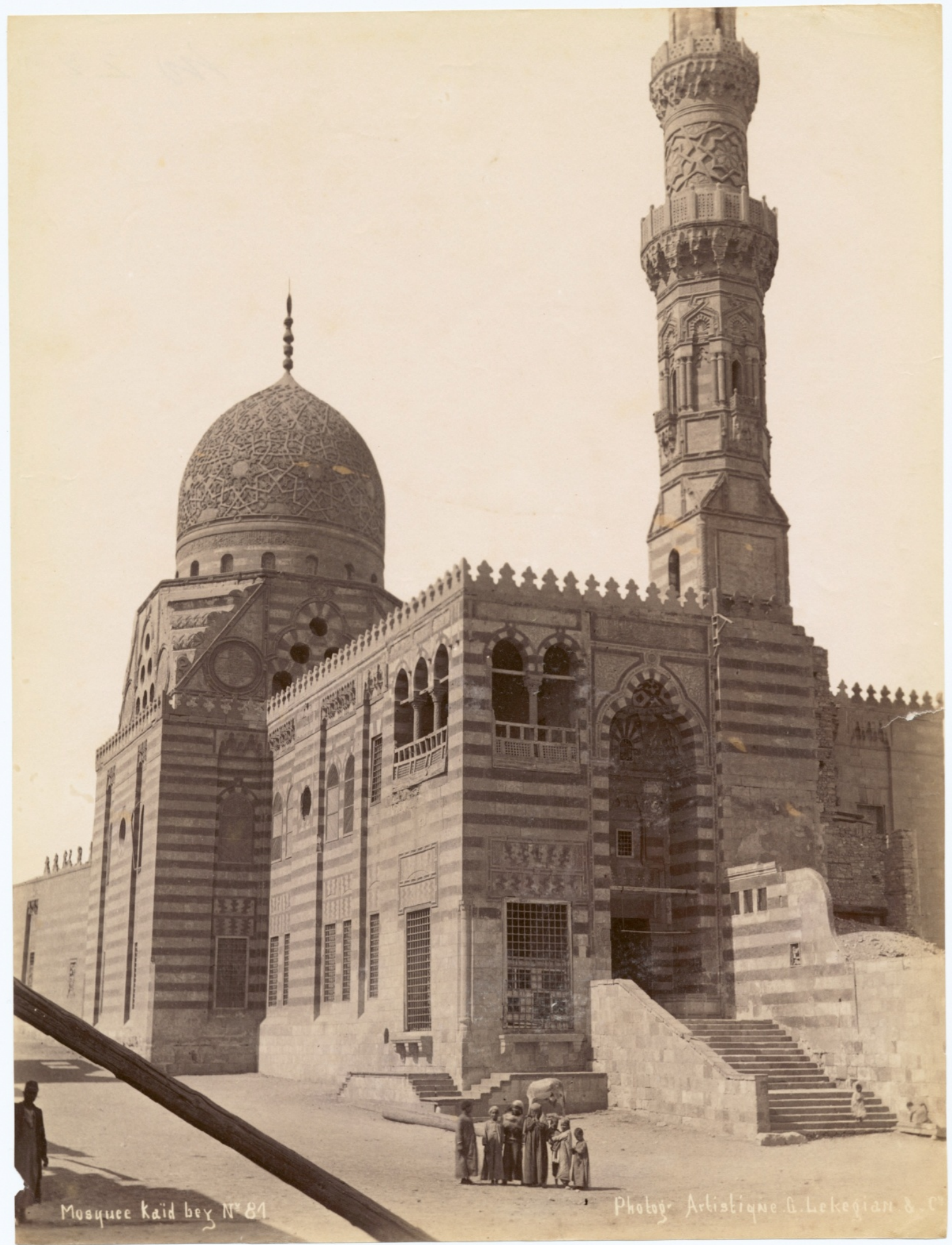

Figure 8. Gabriel Lekegian, Mosquée Kaïd bey, 1887-1890

Image courtesy of the New York Public Library. Reproduced by permission of the New York Public Library. (C) Gabriel Lekegian 


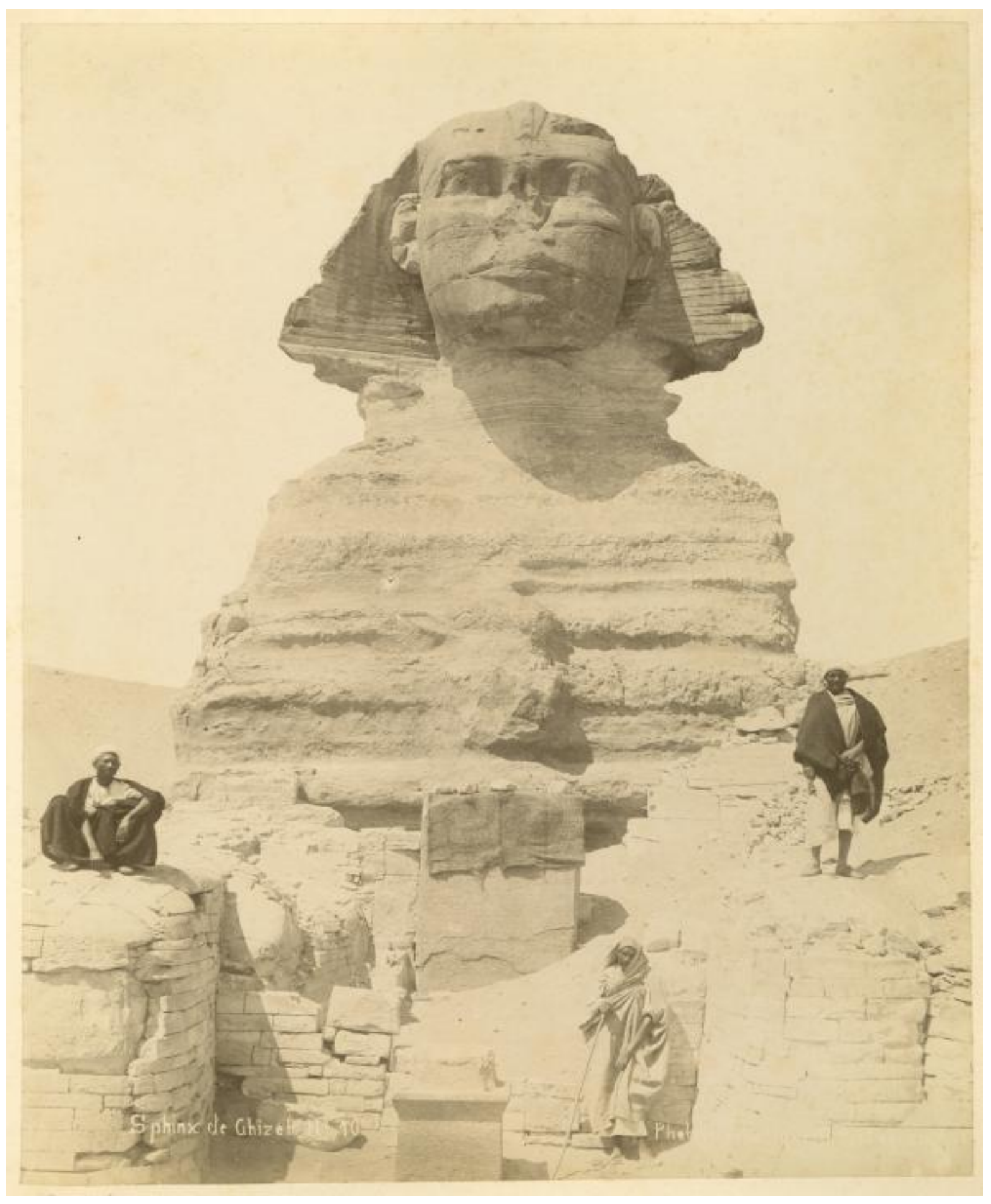

Figure 9. Gabriel Lekegian, Sphinx de Ghizeh No. 10., 1887-1890

Image courtesy of the New York Public Library. Reproduced by permission of the New York Public Library.C Gabriel Lekegian 


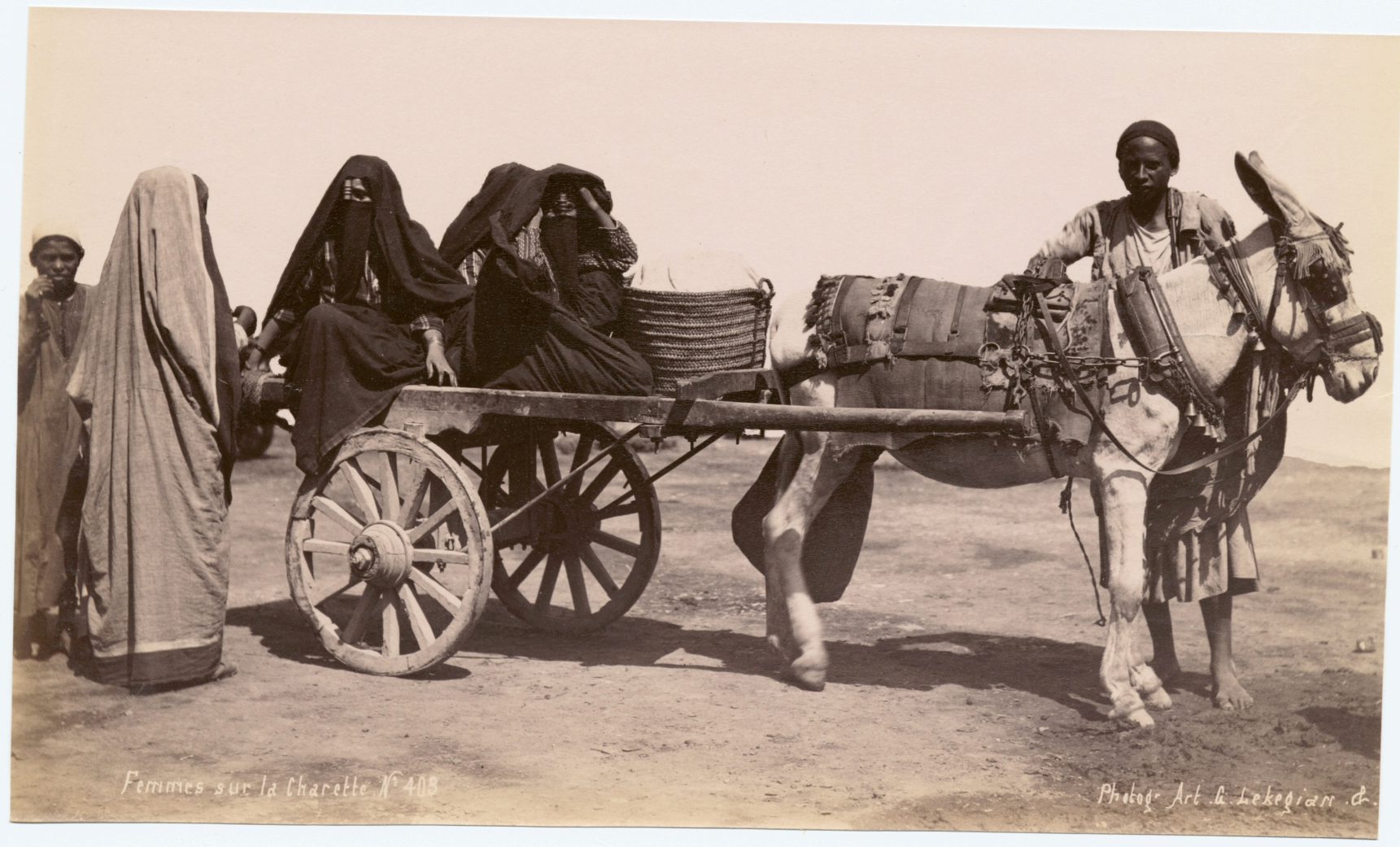

Figure 10. Gabriel Lekegian, Femmes sur la charette, 1887-1890

Image courtesy of the New York Public Library. Reproduced by permission of the New York Public Library. C Gabriel Lekegian 


\section{Case Study: Pascal Sébah and Jean Pascal Sébah}

Born in Istanbul, 1823, Pascal Sébah (fig.13) was the fourth child of Hanna (Joannis, Jean) Sébah, a Syrian Catholic and Lisa Hichaftadjian, an Armenian. ${ }^{51}$ In 1857 he opened his first studio, "El Chark" (The Orient) at number 10 Tom Tom Sokaği, the street where the Austrian Post Office was situated and which was the continuation of the Rue de Postes. ${ }^{52}$ In 1858 he was able to move his studio to 232 Grande Rue de Pera in Istanbul's Pera District, where the Abdullah Frères had also opened photography studios alongside their European counterparts. Meanwhile his original studio on Tom Tom Sokaği remained open and was used as a laboratory.

Early in his career, Sébah's skills as a photographer, in particular his control of tonality and composition, earned him a reputation in Istanbul, and in 1859 the Société Française de Photographie in Paris awarded him a medal for his work. At the time he was known for his photographs of staged studio scenes of models in local costumes, mosques, bazaars, and other sights of the city. His work was extremely popular with tourists.

Alongside Sébah were the renowned Abdullah Frères, who carried out all types of photographic commissions for the Ottoman palace and for the Sultan. While Sébah was a competitor with the Abdullah Frères, he chose to conduct his business outside of the Ottoman palace and did not rely on the coveted title of "Photographer by Appointment of the Sultan" to make his career as other famous studios did. Instead, he continued to participate in international expositions and gained awards and recognition in Paris (1870), Vienna (1873), Philadelphia

\footnotetext{
${ }^{51}$ Engin Özendes, From Sébah \& Joaillier to Foto Sabah: Orientalism in Photography (Istanbul: Yapi Kredi Publications, 1999), 173.

${ }^{52}$ Özendes, From Sébah \& Joaillier to Foto Sabah: Orientalism in Photography, 175.
} 
(1877) and Naples. He was also a recognized as a member of the Société Française de Photographie in Paris and at the Paris Exposition in $1867 .^{53}$

The year 1873 was a particularly good one for Sébah's career due to two happenings. The first was his meeting with the Ottoman diplomat and founder of Istanbul's Academy of Fine Arts, Osman Hamdi Bey (1842-1910), who introduced Sébah to Istanbul's artistic communities. The other was the exhibition of his work at the 1873 International Exposition in Vienna. ${ }^{54}$ Upon meeting Sébah, who had proved himself expert in the new art of photography with the refined elegance of his style, Osman Hamdi Bey commissioned Sébah to depict the ethnic diversity of the peoples of the Ottoman Empire for an album titled Les Costumes Populaires de la Turquie en 1873 (fig. 12). The album includes a series of plates depicting male and female models posing against plain studio backdrops in regional costumes and jewelry. Each plate was accompanied by an explicatory text in French. ${ }^{55}$ The volume was presented as part of the official Ottoman imperial exhibition for the Exposition in Vienna. Thus, in addition to his commercial success, Sébah also played a role in Ottoman imperial image making by demonstrating his skill in the creation of official images that served state purposes. Sébah was awarded a medal from the exposition for the album. Following this success, Pascal Sébah was able to open another studio in Egypt at the end of 1873 next to the famous Shepheard's Hotel in Cairo, where Gabriel Lekegian later practiced photography across the street. ${ }^{56}$ His photographs now included landscapes, urban scenes, markets and buildings of Alexandria, Cairo and Nubia as he continued to travel between Istanbul and Cairo, and to show his work at international exhibitions.

\footnotetext{
${ }^{53}$ Sheehi, The Arab Imago, 7.

${ }^{54}$ Özendes, From Sébah \& Joaillier to Foto Sabah, 180.

55 Osman Hamdi, Marie de Launay and Pascal Sébah, Les Costumes Populaires de la Turquie en 1873 (Istanbul, 1873).

${ }^{56}$ Özendes, From Sébah \& Joaillier to Foto Sabah, 199.
} 
Unfortunately at the height of his career, the demands of owning and managing businesses in two different cities took a toll on Pascal Sébah. ${ }^{57} \mathrm{He}$ suffered a brain hemorrhage in 1883 that left him paralyzed; he was no longer able to work and his children were still too young to take over his business. On June 25 1886, after three years of being bedridden, Pascal Sébah died, leaving behind his wife, daughter and two sons. His younger brother Cosmi, who had opened his own photography studio in 1880 , closed down his studio and took over the management of Pascal Sébah's studio. ${ }^{58}$ Sébah was buried in the Latin cemetery in Ferikoy, Turkey.

Although Cosmi Sébah managed the studio, its rightful heirs were Pascal's children. By 1888, Pascal Sébah's eldest son, Jean Pascal Sébah (1872-1947), then 16 years old, had begun to take an interest in his father's business, and with his uncle's help and training went into partnership with French photographer, Policarpe Joaillier (1848-1904). ${ }^{59}$ The renowned Sébah \& Joaillier (fig. 11) was a huge success from the beginning, and the Cairo branch was reactivated.

After entering into partnership with Joaillier, Jean Pascal Sébah followed in his father's footsteps, continuing to photograph scenes and people of Constantinople (by far the most photographed city), Greece and Egypt, including the Nubians. In 1893, Sultan Abdulhamid made a gift to both the Library of Congress and the British Library of fifty-one photographic albums representing the span of the Ottoman Empire and its modernization, two of which were produced by Sébah \& Joaillier. In 1900, in order to pay their debts, the Abdullah Frères sold their studio along with their negatives and equipment to Sébah \& Joaillier, further expanding the Sébah \& Joaillier brand. The Sébah name lasted for some time, becoming Foto Sabah in 1934 until eventually closing in 1953 . Through only one monograph has been published about the Sébah

\footnotetext{
${ }^{57}$ Ibid, 208.

${ }^{58}$ Ibid.

${ }^{59}$ Ibid, 209.
} 
family and its studio, the photographers' names are mentioned frequently, albeit briefly, in histories of photography from the Middle East.

The NYPL's Photography Collection's collection database contains three constituent records that are associated with the Sébah family business: Pascal Sébah, Jean Pascal Sébah and Sébah \& Joailler. While the father-son duo did not work together, their photographs are often hard to distinguish as they shared the same last name and signed their photographs in a similar manner. The subject matter and style of their photographs are also similar. Nevertheless, Jean Pascal was a noted photographer in his own right and care must be taken not to confuse his work with that of his father Pascal Sébah - as occurs in a number of online databases and publications such as Nissan Perez's Focus East.

The NYPL contains a total of fifty-three images by Pascal Sébah. Fifty-one of which belong to an album of collotypes, titled Haute-Egypte et Nubie par Pascal Sébah, which previously belonged to the Library's General Research Division. The title is embossed in gold on the front cover of the album and includes a table of contents (titles, plate numbers numbered 1 through 50) in French letterpress. The photographs range from landscapes, ancient monuments and structures to naval scenes, and portraits of locals. Copies of this album also belong to a number of other institutions including Princeton University Library in Princeton, New Jersey and the Canadian Centre for Architecture in Montreal, Quebec. The Photography Collection also includes one cabinet card of an unidentified women and one albumen photograph that I retrieved depicting the columns of the temple of Esneh in Egypt.

There are twenty objects attributed to Jean Pascal Sébah, including twelve photographs from an album of photographs of Pakistan, Egypt and European locations (figs. 14-21), and eight 
photographs dispersed throughout various albums in the NYPL's Photography Collection. These albums contain photographs by many other photographers. All are in poor condition and need more in-depth research, descriptions and item level cataloguing. Finally, there are thirty-eight loose albumen prints attributed to Sébah \& Joaillier, including thirty-three donated by BritishAmerican literary translator Peter Constantine in 2011 and five transferred from the Picture Collection.

Like Lekegian's, the Sébah family's catalogue records do not accurately reflect their ethnic identities. Likwise in Getty's ULAN Database, the Sébah family has been catalogued as being "Turkish.” The Sébah's, like Lekegian were Ottoman subjects. While both Pascal Sébah and Jean Pascal Sébah were born and worked in what is today Istanbul, Turkey, to describe them as "Turkish" is incorrect. In the $19^{\text {th }}$ century, the word "Turk" only referred to Anatolian villagers. The Ottoman ruling class identified themselves as Ottomans, not usually as Turks. ${ }^{60}$ During Ottoman times, the millet system defined communities on a religious basis, and a residue of this remains in that Turkish villagers commonly consider as Turks only those who profess the Islamic faith. Turkish Jews and Christians are considered non-Turks. ${ }^{61}$ For that reason alone, these photographers should definitely not be called "Turkish", but "Ottoman", or more specifically "Syrian-Armenian".

\footnotetext{
${ }^{60}$ David Kushner, "Self-Perception and Identity in Contemporary Turkey," Journal of Contemporary History, 32 (1997): 219, accessed August 1, 2017, http://www.jstor.org/stable/261242.

${ }^{61}$ Michael Meeker, "The Black Sea Turks: Some Aspects of Their Ethnic and Cultural Background," International Journal of Middle East Studies 2 (1971): 322, accessed August 1, 2017, http://www.jstor.org/stable/162721.
} 


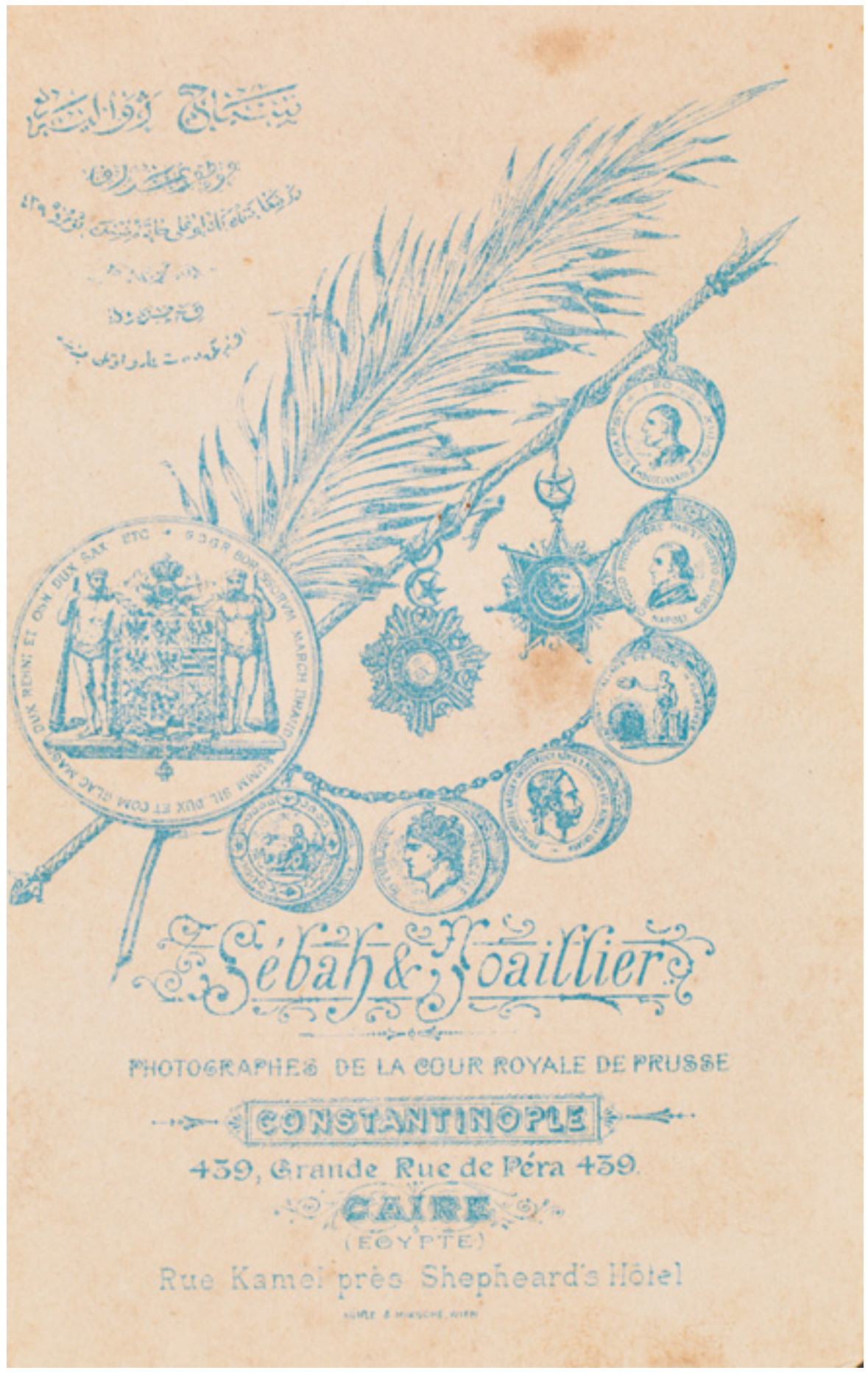

Figure 11. The studio of Sébah \& Joaillier, ca 1890-1910

Image courtesy of the Ömer M. Koç Collection. (C) Ömer M. Koç Collection 


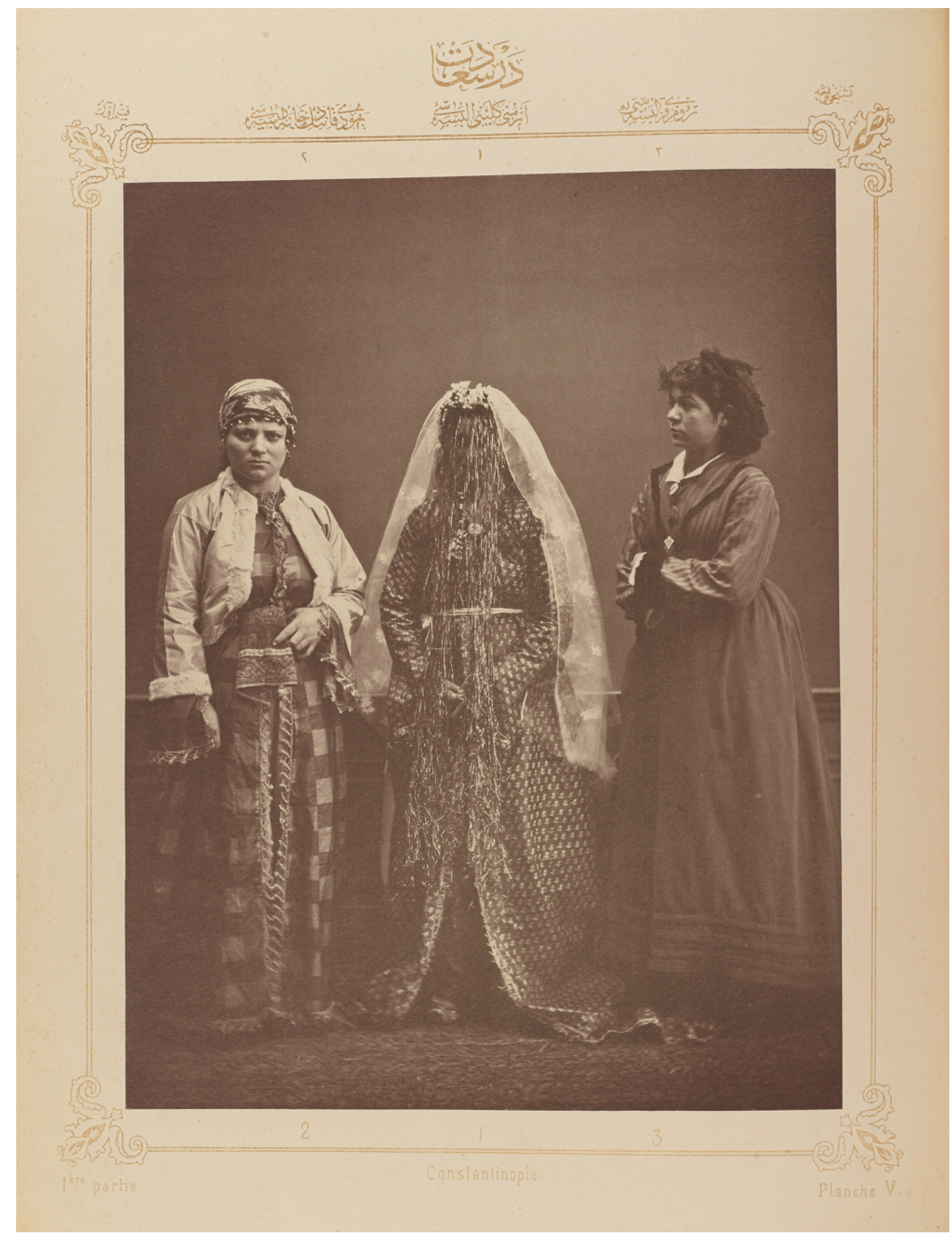

Figure 12. Pascal Sébah, Constantinople: Armenian Bride, from Les costumes populaires de la Turquie en 1873: ouvrage publié sous le patronage de la Commission impériale ottomane pour l'Exposition universelle de Vienne.

Image courtesy of the Getty Research Institute. (C) The Getty Research Institute 


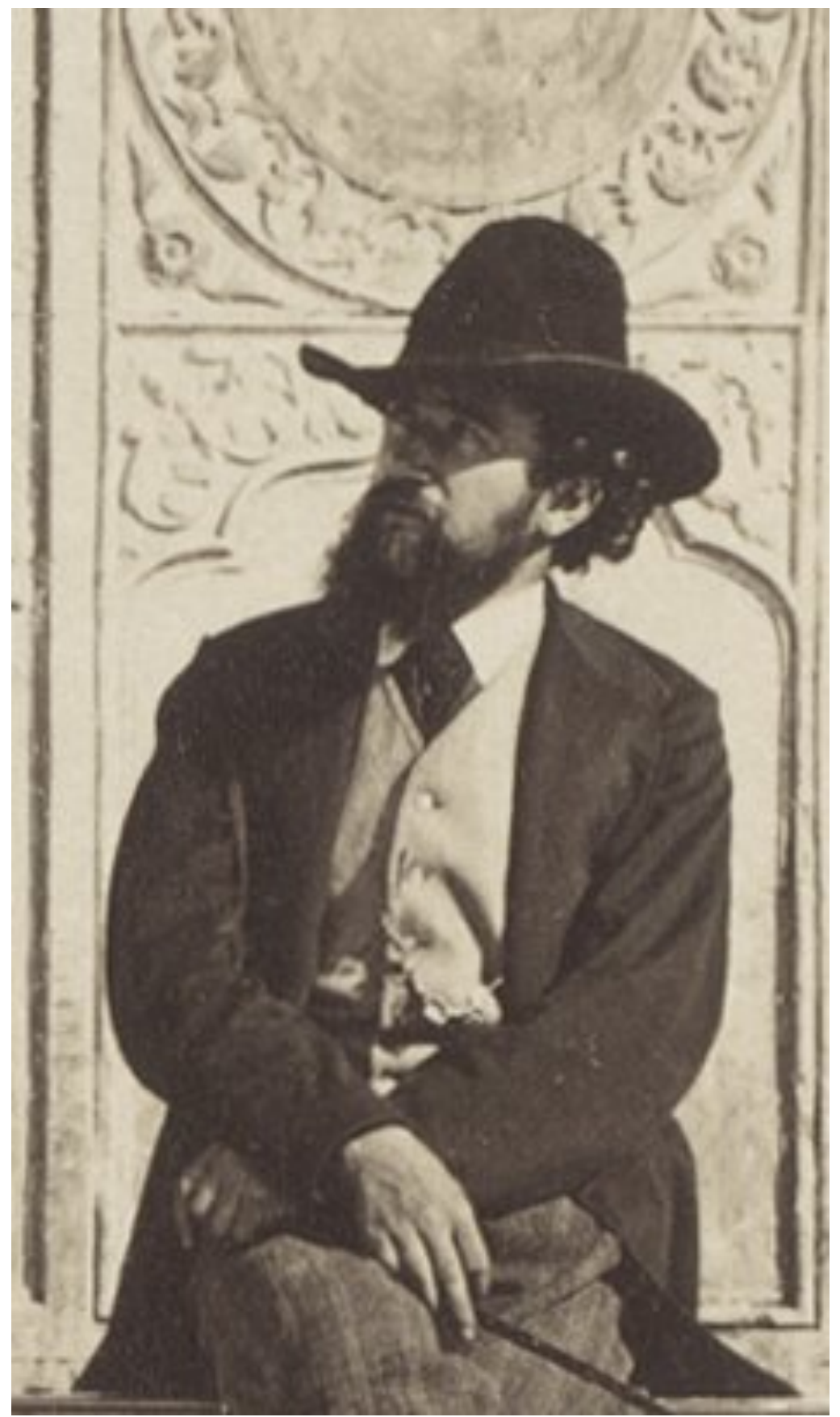

Figure 13. Pascal Sébah, The Fountain of Sultan Ahmet III in Istanbul, detail, [Portrait of Pascal Sébah] circa 1870.

Image courtesy of the Guimet Museum of Asian Art. (C) Guimet Museum of Asian Art 


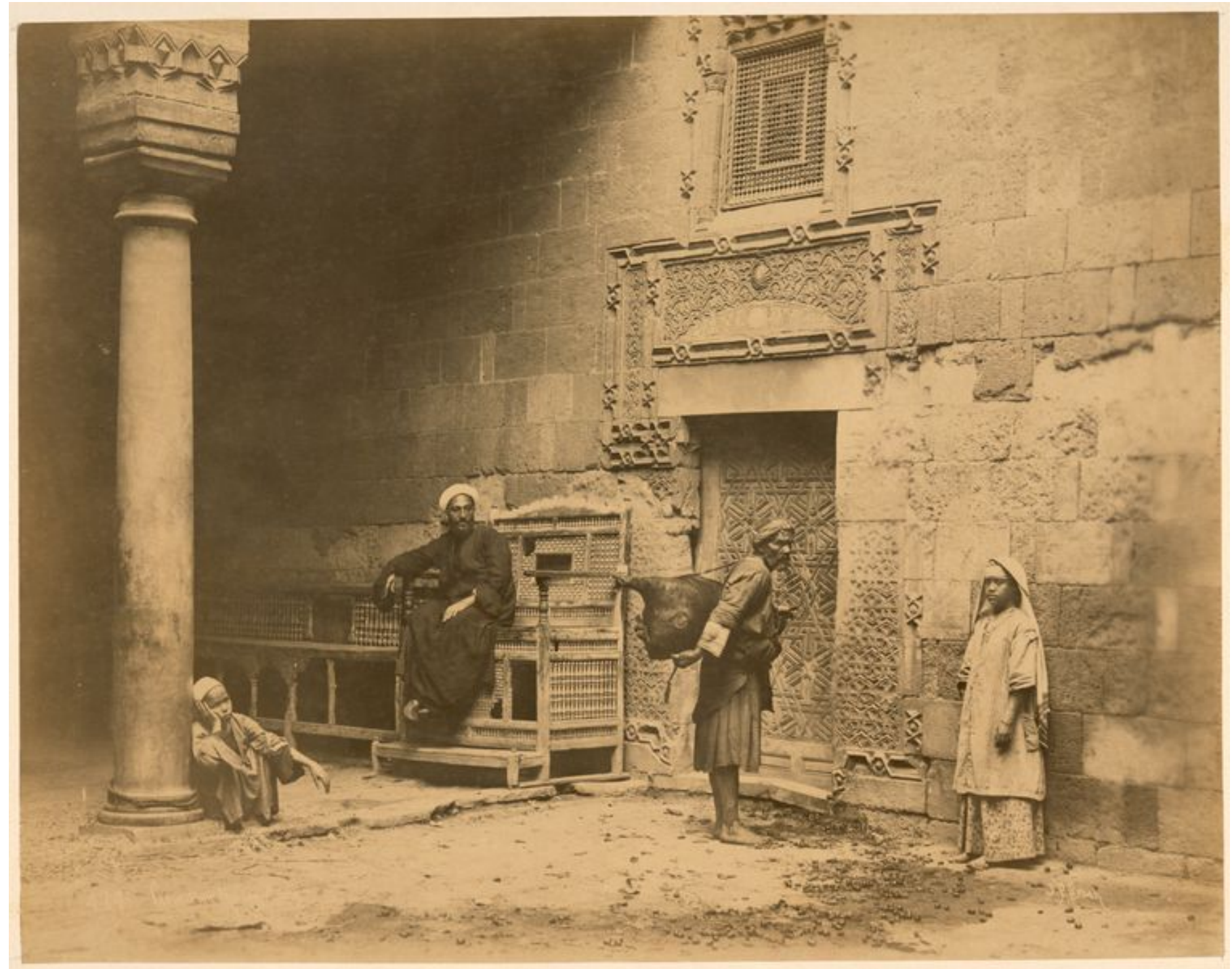

Figure 14. Jean Pascal Sébah, [Two men, woman and boy by carved door], 1888-1900

Image courtesy of the New York Public Library. Reproduced by permission of the New York Public Library. (C) Jean Pascal Sébah 


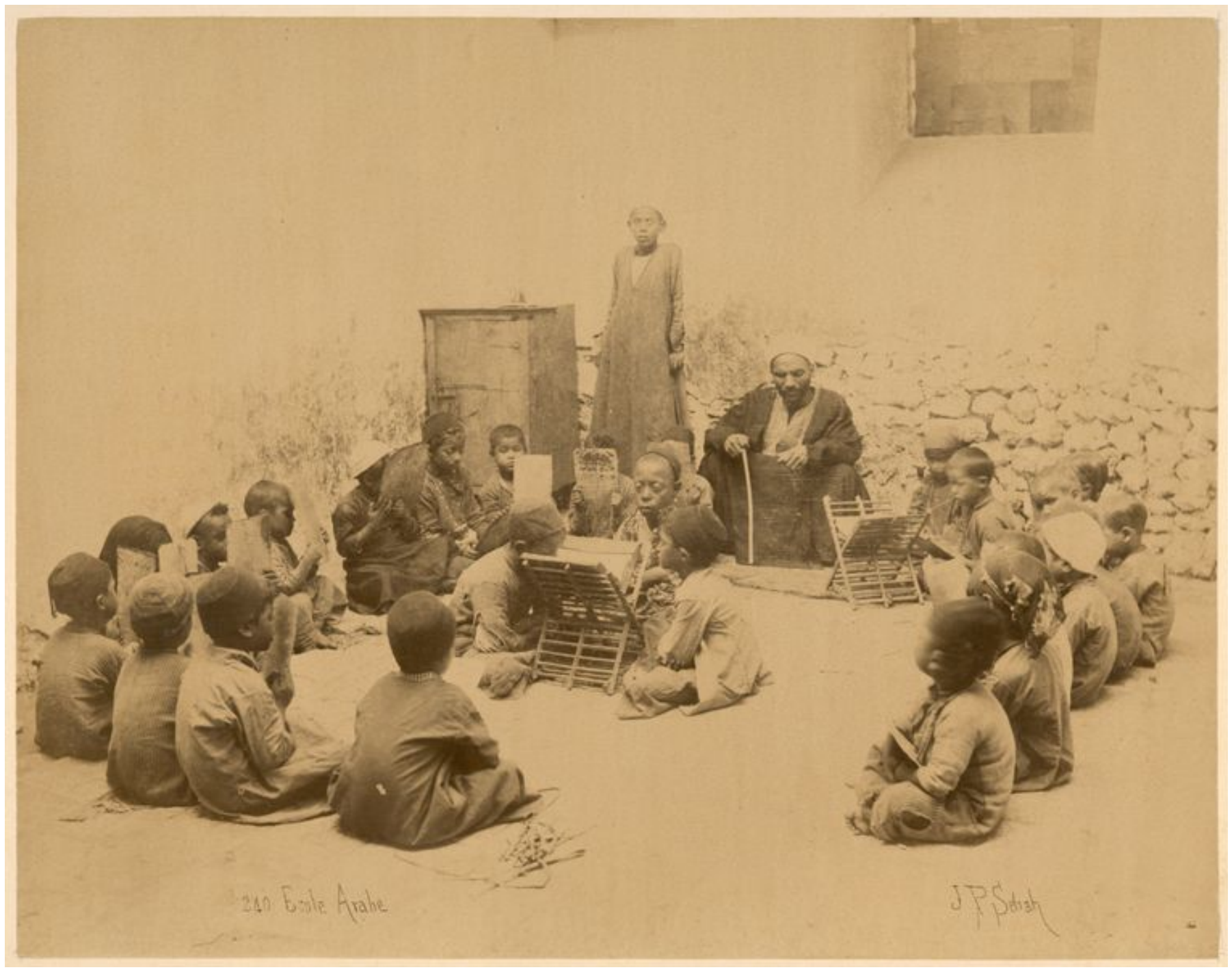

Figure 15. Jean Pascal Sébah, Ecole arabe, 1888-1900

Image courtesy of the New York Public Library. Reproduced by permission of the New York Public Library. (C) Jean Pascal Sébah 


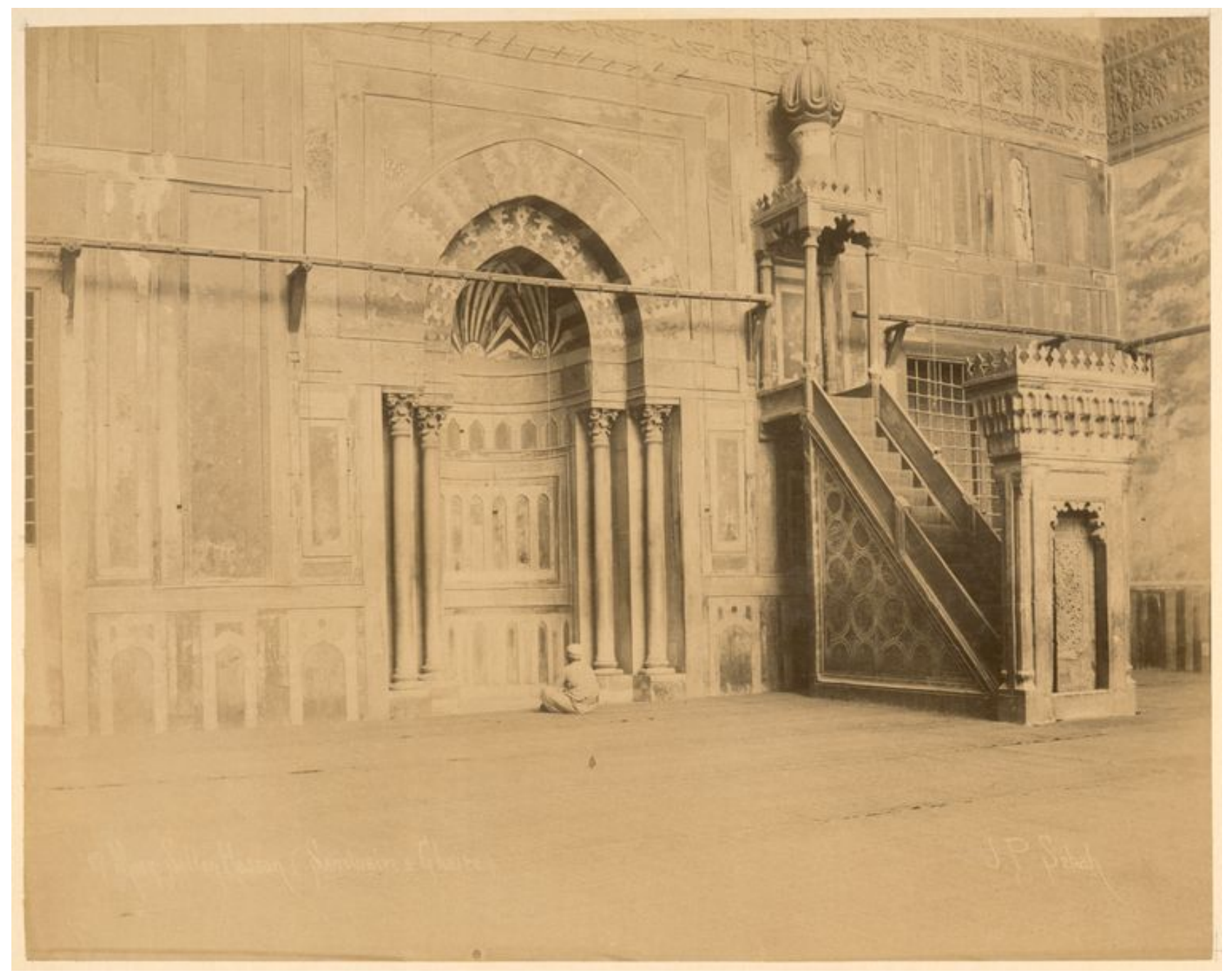

Figure 16. Jean Pascal Sébah, Mosque of Sultan Hassan, interior, 1888-1900

Image courtesy of the New York Public Library. Reproduced by permission of the New York Public Library. (C) Jean Pascal Sébah 


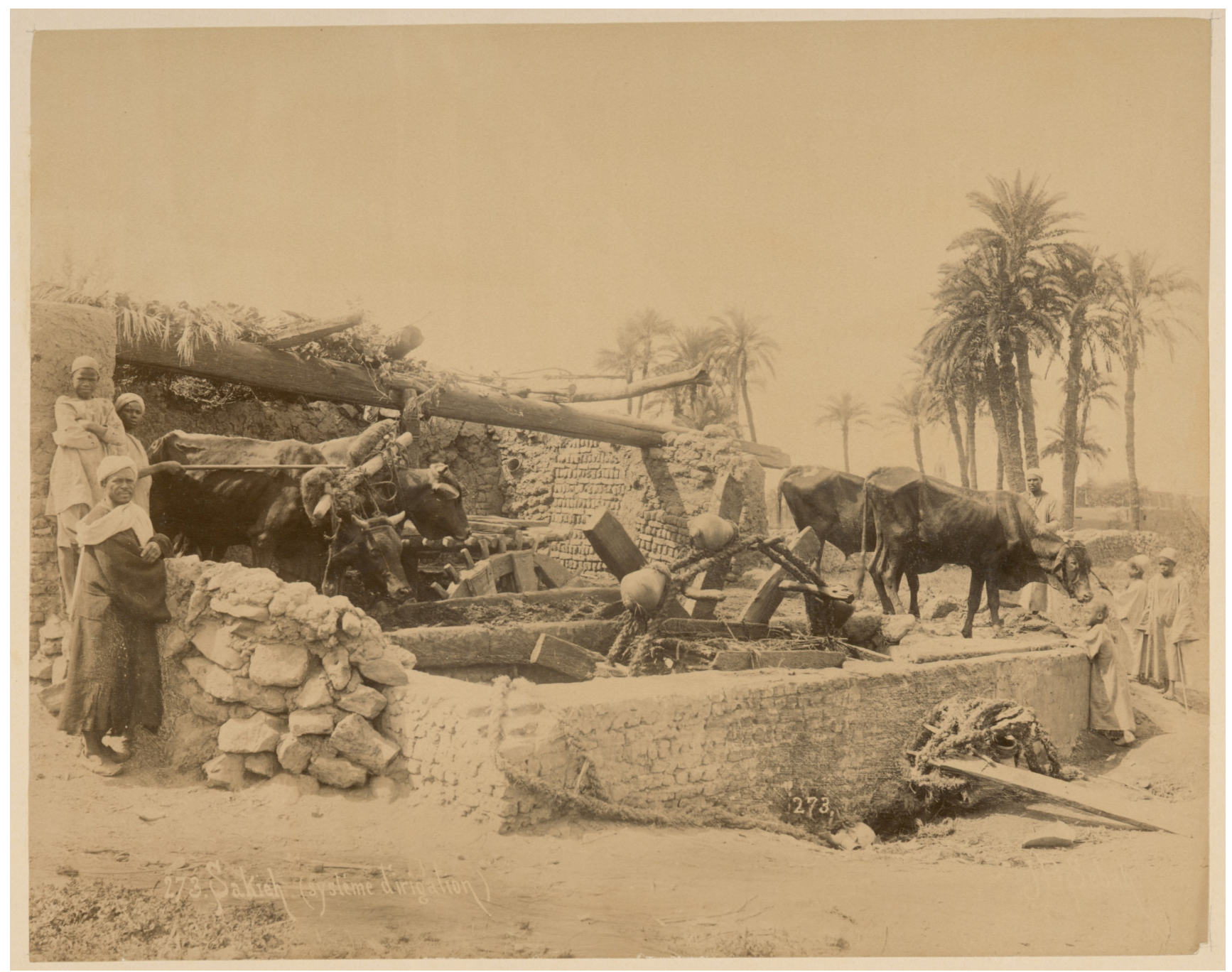

Figure 17. Jean Pascal Sébah, Sakieh (système d'irrigation), 1888-1900

Image courtesy of the New York Public Library. Reproduced by permission of the New York Public Library.C Jean Pascal Sébah 


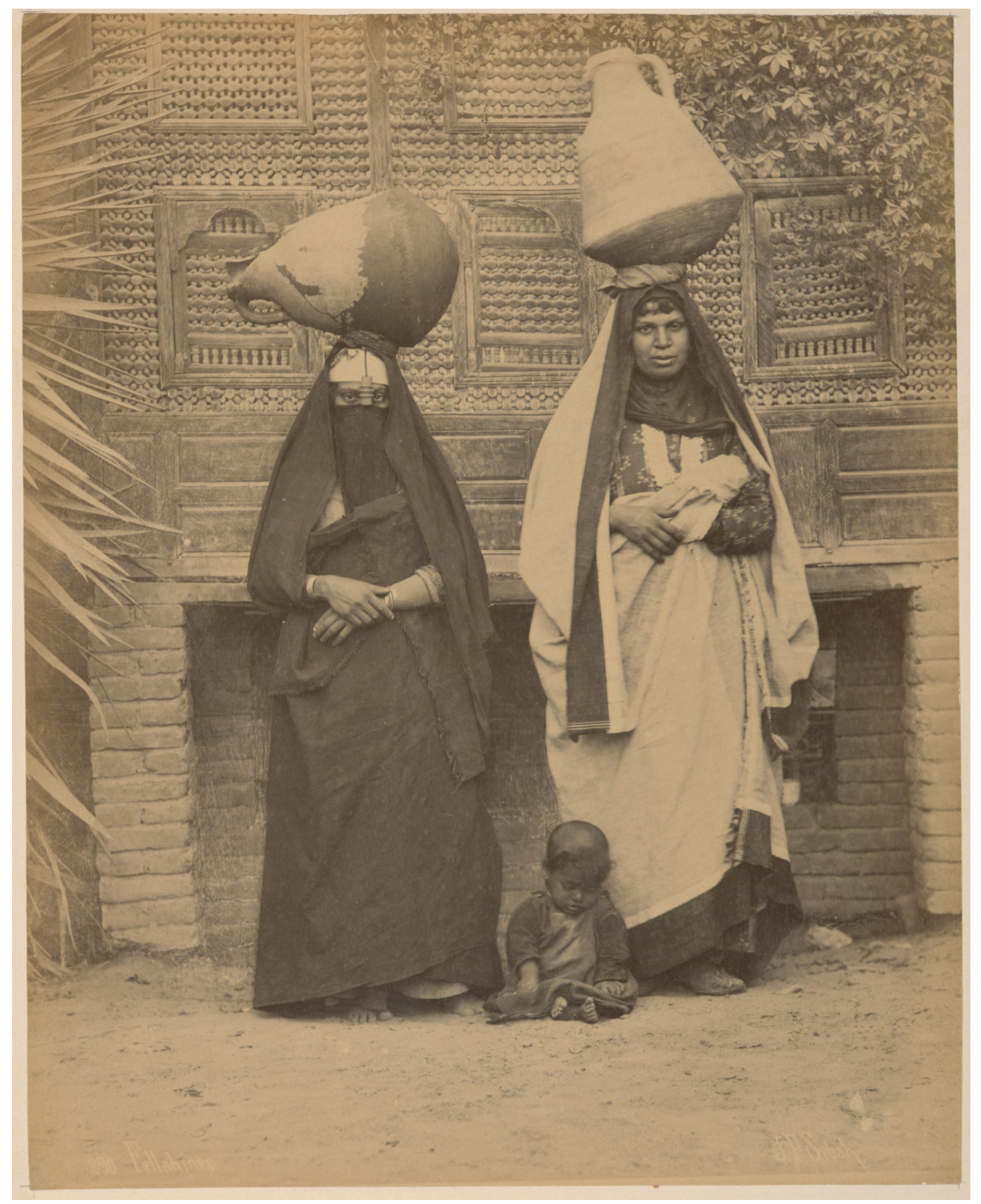

Figure 18. Jean Pascal Sébah, Fellahines, 1888-1900

Image courtesy of the New York Public Library. Reproduced by permission of the New York Public Library. (C) Jean Pascal Sébah 


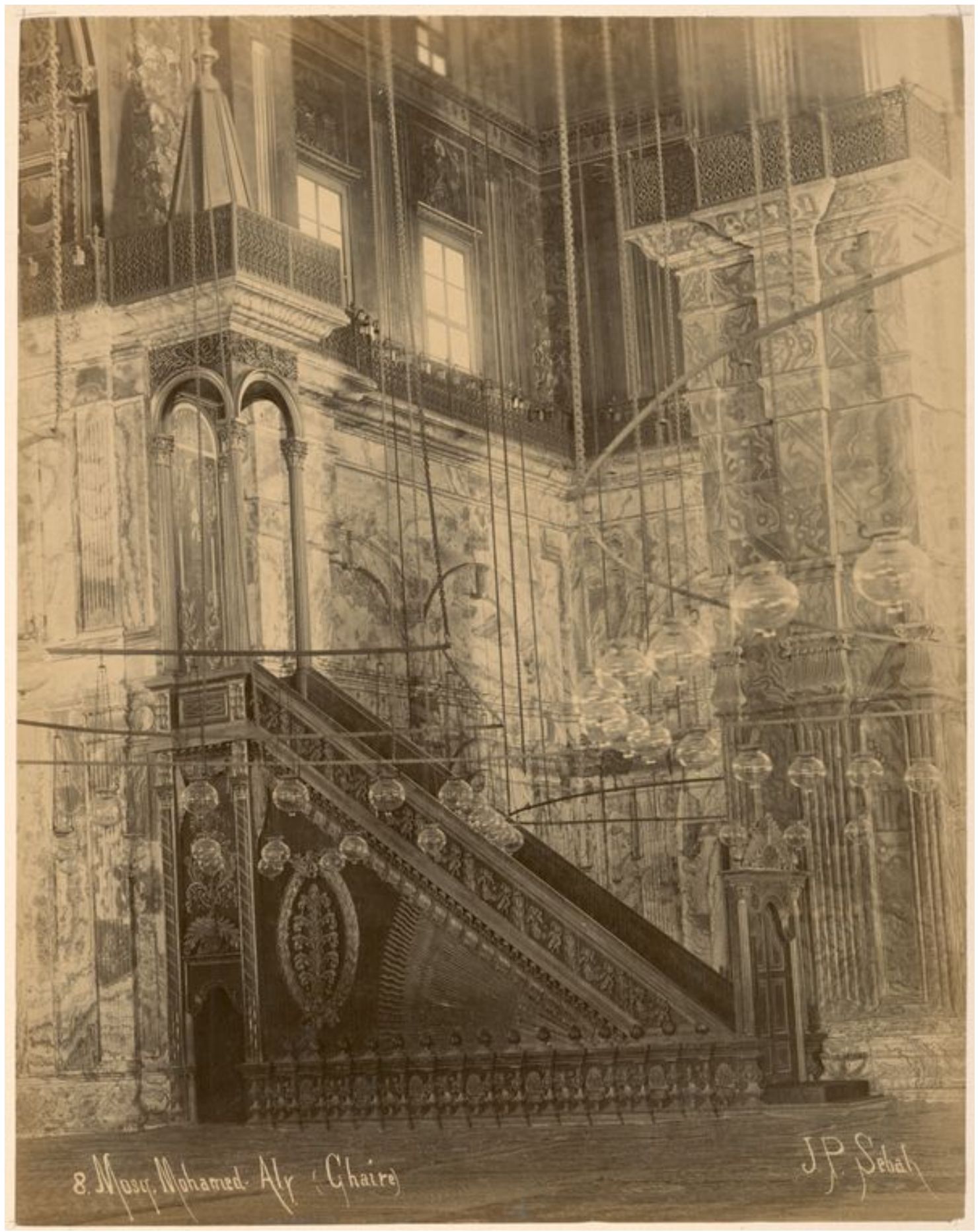

Figure 19. Jean Pascal Sébah, Mosq. Mohamed Ali (Chaire), 1888-1900

Image courtesy of the New York Public Library. Reproduced by permission of the New York Public Library.C Jean Pascal Sébah 


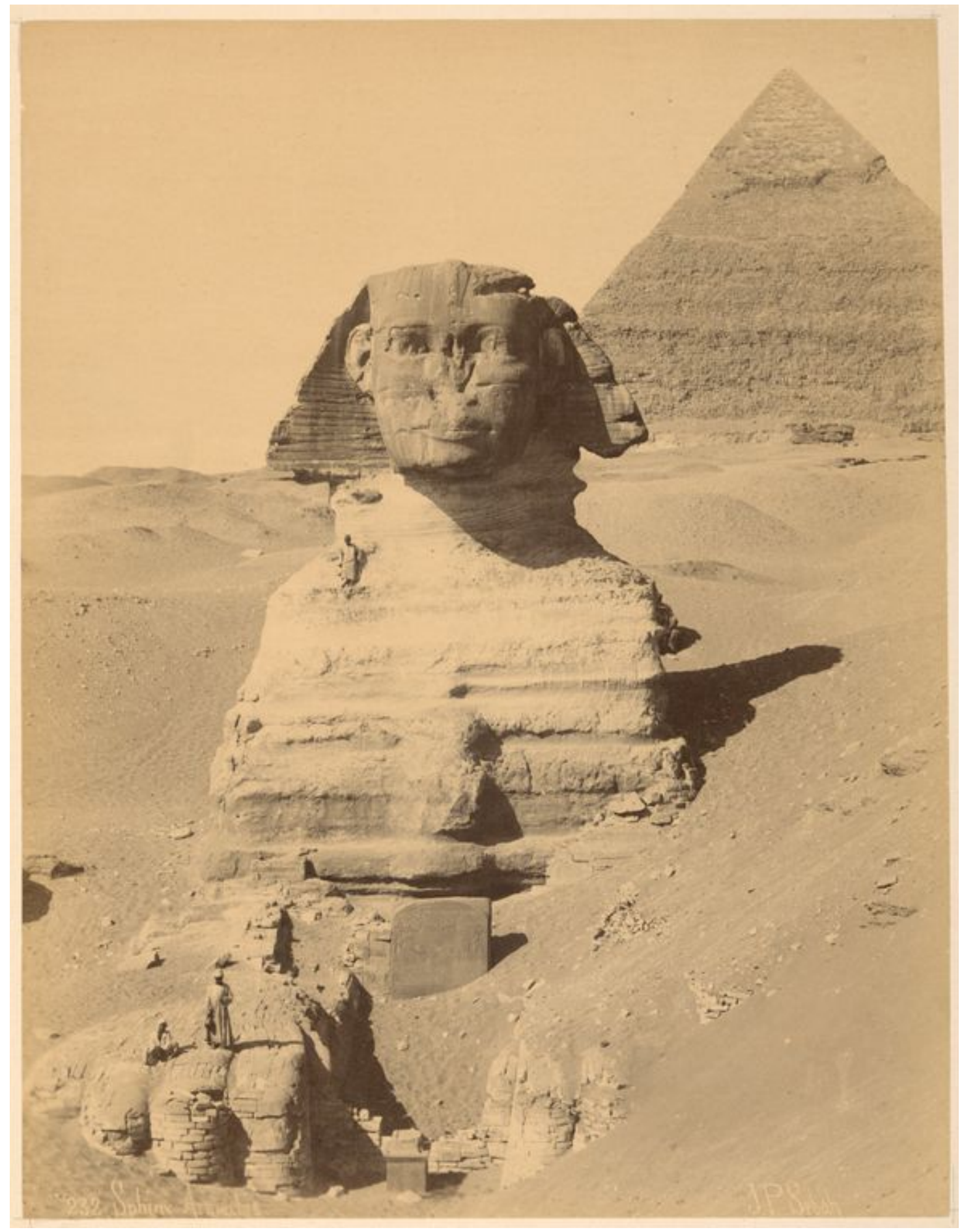

Figure 20. Jean Pascal Sébah, Sphinx Armachis [neg.232], 1888-1900

Image courtesy of the New York Public Library. Reproduced by permission of the New York Public Library.C Jean Pascal Sébah 


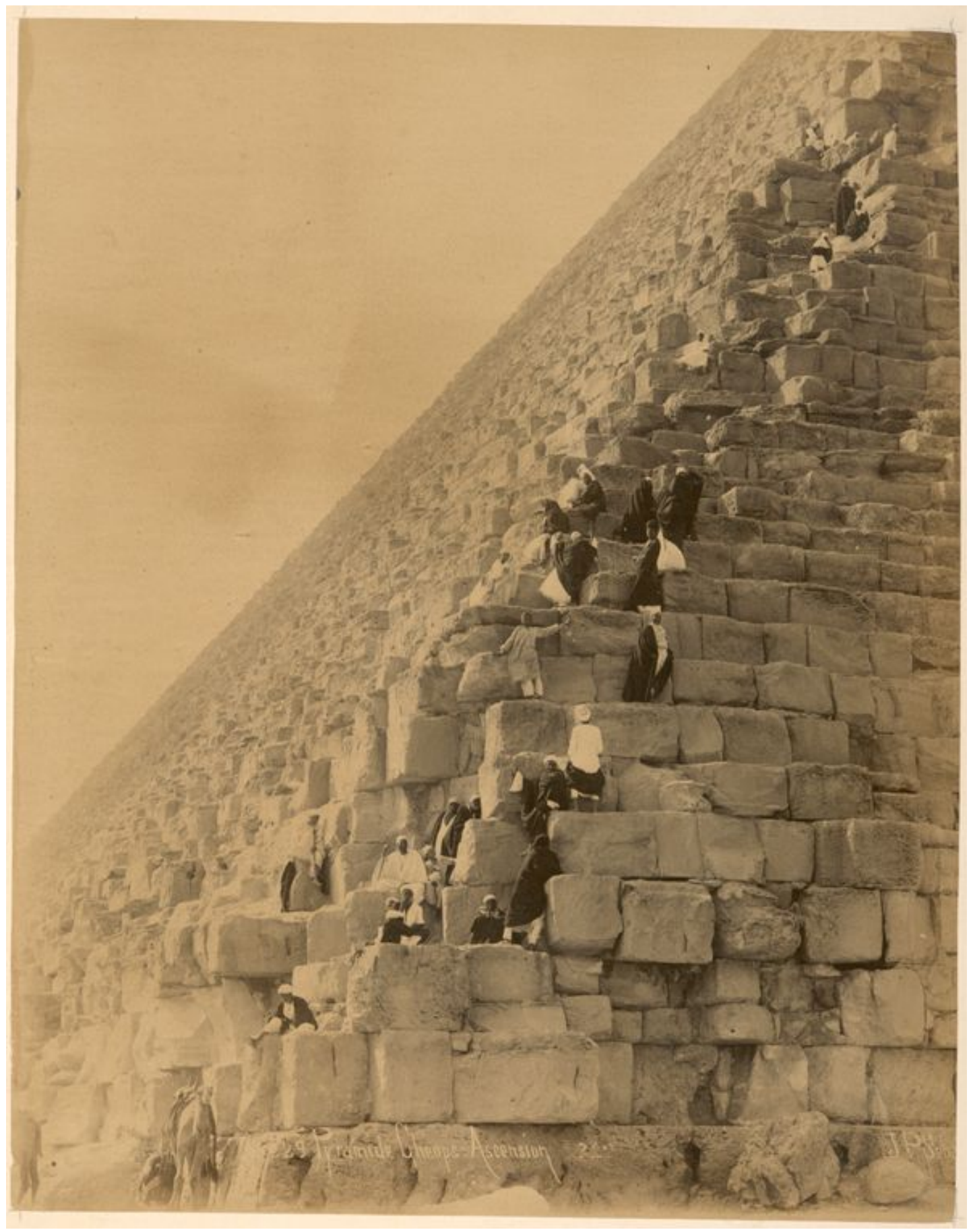

Figure 21. Jean Pascal Sébah, Pyramide Cheops: ascension [neg.229] 1888-1900

Image courtesy of the New York Public Library. Reproduced by permission of the New York Public Library. (C) Jean Pascal Sébah 


\section{Conclusion}

The case studies explored in this thesis have demonstrated that ethnic status, in the case of the Armenian community, is fundamental to the practices and traditions of Ottoman photography. As I hope I have shown, the ethnic identities of Gabriel Lekegian, Pascal Sébah and Jean Pascal Sébah are grounded in traditions quite different from the French or other European traditions. Armenian traditions, including their artistic merits, technical proficiency and business prowess, in addition to their status as non-Muslims, are distinct products of the Ottoman Empire's middleclass ethnic minority cultures and came to bear on their photographic practices or will be seen to do so once the practitioners are identified within these traditions.

To mistake their ethnicity is therefore to limit our understanding of the nature of indigenous photography in the Ottoman Empire and to differentiate its traditions from those of the West. Without this distinction, we will not be able to identify the particular aspects or aesthetic qualities inherent in the Armenian photographic tradition. Such knowledge enhances our understanding of the photographs and is important when considering their circulation value. More importantly, by identifying Armenian creators within Ottoman photographic history, we can challenge and disrupt those deeply rooted or newly constructed historiographic structures which continue to eradicate, erase and silence contributions made by Ottoman-Armenians. By reestablishing these ethnic identities, we will be able to gain a more accurate, nuanced and complete picture of Ottoman photographic history.

As I have shown, these types of errors are symptoms of catalogue records that are not up to date with current research emphasizing the role of ethnic minorities in Ottoman photographic practices. While my focus is largely on photographic material from the late Empire, the issues 
addressed are relevant to a broader understanding of historical photographic works and collections and can be translated to other minority contexts. Of course, this work is intended as one small step towards a reframing of Ottoman photography and is far from being conclusive. There remains much more to be done in order to return to art and photographic history the voices of all Ottoman creators, be they Greek, Jewish, Levantine, Assyrian, Kurdish or others, who have until recently been kept silent. Given the knowledge that has accumulated on the history of Ottoman photography as a result of this research and the evolving scholarship produced by an ever greater number of collectors and scholars, I believe we can aspire to a more representative and inclusive understanding of photography in the Ottoman Empire than has so far been possible. 


\section{Bibliography}

Ali, Mehmed. Yousuf Karsh \& John Garo: The Search for a Master's Legacy. Massachusetts: Benna Books, 2015.

Armenian Immigration Project. “Abstracts of Primary Source Material for the Study of Armenian Immigration to North America through 1930.” Accessed June 7, 2017. mhttp://arslanmb.org/ArmenianImmigrants/Public-ViewSummary-ArmenianImmigrants-MainByJoiningAddress.php?SelectJoiningCountry=USA\&SelectJoiningStateProvince=IL\&SelectSort Order=ByStreetAddress\&Staging $=$.

Azadian, Edmond Y. "Looters or Landlords?" The Armenian Mirror Spectator, October 3, 2012. Accessed April 30, 2017. http://www.mirrorspectator.com/2012/10/03/looters-or-landlords/.

Behdad, Ali. Camera Orientalis: Reflections on Photography of the Middle East. Chicago: University of Chicago Press, 2016.

Behdad, Ali and Luke Gartlan, eds. Photography's Orientalism: New Essays on Colonial Representation. Los Angeles: Getty Research Institute, 2013.

Bilefsky, Dan. "Seeking Return of Art, Turkey Jolts Museums." The New York Times, September 30, 2012. Accessed April 30, 2017. http://www.nytimes.com/2012/10/01/arts/design/turkeysefforts-to-repatriate-art-alarm-museums.html.

Brown, Julie. Contesting Images: Photography and the World's Columbian Exposition. Arizona: University of Arizona Press, 1994.

Çelik, Zeynep and Edhem Eldem. Camera Ottomana: Photography and Modernity in the Ottoman Empire, 1840-1914. Istanbul: Koç University, 2015.

Chevedden, Paul E. The Photographic Heritage of the Middle East: An Exhibition of Early Photographs of Egypt, Palestine, Syria, Turkey, Greece and Iran, 1849-1893. Malibu: Undenda Publications, 1981

Cleveland, William. A History of the Modern Middle East. Boulder: Westview Press, 2013.

"Conflicted Visions: Gabriel Lekegian and the Oriental Imagination." Lusadaran: Armenian Photography Foundation, 2015. Accessed May 5, 2017. http://lusadaran.org/2011/11/conflictedvisions-gabriel-lekegian-and-the-oriental-imagination/.

Davidian, Vazken. "Reframing Ottoman Art Histories: Bringing Silenced Voices Back into the Picture.” Études arméniennes contemporaines, 6 (2015): 7-17. Accessed June 3, 2017. https://eac.revues.org/875 
El-Hage, Badr. "The Armenian Pioneers of Middle Eastern Photography." Journal of Palestine Studies, 31 (2007): 22-26. Accessed March 7, 2017. http://www.palestine-

studies.org/sites/default/files/jq-articles/31_hage_1.pdf

Eldem, Edhem. "Greece and the Greeks in Ottoman History and Turkish Historiography." The Historical Review/La Revue Historique, 6 (2009): 27-40. Accessed June 3, 2017. http://www.academia.edu/7824241/Greece_and_the_Greeks_in_Ottoman_History_and_Turkish_ Historiograpy

Eldem, Edhem. "Powerful Images: The Dissemination and Impact of Photography in the Ottoman Empire, 1870-1914." In Photography and Modernity in the Ottoman Empire 19401914, edited by Zeynep Çelik and Edhem Eldem, 106-153. Istanbul: Koç University Publications, 2015.

"Facts regarding misappropriation of Armenian art by Azerbaijan and Turkey will be represented to ICOM." ArmenPress, October 22, 2012. Accessed April 30, 2017.

https://armenpress.am/eng/news/696984/facts-regarding-misappropriation-of-armenian-art-byazerbaijan-and-turkey-will-be-represented-to-icom.html.

Ferri, Antonio. Memoires d'Egypte : da un album fotografico del 1895 : fotografie di Beato, Bonfils, Lekegian, Reiser / a cura di Antonio Ferri. Bologna: Bononia University Press, 2010.

Gantzhom, Volkmar. The Christian Oriental Carpet. Cologne: Taschen, 1991.

Golia, Maria. Photography and Egypt. London: Reaktion Books LTD, 2010.

Grillot, Marie. "Gabriel Lekegian, l'artiste photographe." Egyptophile, June 21, 2014. Accessed May 10, 2017. http://egyptophile.blogspot.ca/2014/06/gabriel-Lekegian-lartistephotographe.html.

Grimes, Julia. "Armenians and Armenian Photographers in the Ottoman Empire." The Public Domain Review, November 4, 2014. Accessed March 1, 2017.

https://publicdomainreview.org/collections/armenians-and-armenian-photographers-in-theottoman-empire/

Guerville, A.B. de (Amédée Baillot de). New Egypt. London: Heinemann, 1905.

Hannavy, John, ed. Encyclopedia of nineteenth-century photography. New York: Routledge, 2008 .

Kushner, David. "Self-Perception and Identity in Contemporary Turkey." Journal of Contemporary History 32, no. 2 (1997): 219-33. Accessed August 1, 2017. http://www.jstor.org/stable/261242. 
Leeder, S.H. Veiled Mysteries of Egypt and the Religion of Islam with Photographs by the Author, G Lekegian and P. Dittrich, Cairo. London: E.Nash, 1912.

Lusadaran: Armenia Photography Foundation.” Gabriel Lekegian.” Accessed May 29, 2017. http://lusadaran.org/artists/gabriel-Lekegian/.

Low, David. "Photography and the Empty Landscape: Excavating the Ottoman Armenian Image World." Études arméniennes contemporaines 6, 2015: 31-69. Accessed March 1, 2017. https://eac.revues.org/859

Malikian, Joseph E. The Armenians in the Ottoman Empire: An Anthology and a Photo History. Lebanon: Armenian Catholicosate of Cilicia, 2011.

Marsoobian, Armen Tsolag. Dildilian Brothers: Memories of a Lost Armenian Home. Photography and the Story of an Armenian Family in Anatolia, 1888-1923. Istanbul: Birzamanlar Yacincilik, 2015

Marsoobian, Armen Tsolag. Fragments of a Lost Armenian Homeland: Remembering Armenia. New York City: I.B. Tauris \& Co. Ltd, 2015.

Marsoobian, Armen Tsolag. Reimaging a Lost Armenian Home: The Dildilian Photography Collection. New York City: I.B. Tauris \& Co. Ltd, 2015.

Masters, Bruce. Christians and Jews in the Ottoman Arab World: The Roots of Sectarianism. Cambridge: Cambridge University Press, 2001.

Meeker, Michael E. "The Black Sea Turks: Some Aspects of Their Ethnic and Cultural Background." International Journal of Middle East Studies 2 (1971): 318-45. Accessed August 1, 2017. http://www.jstor.org/stable/162721.

Miller, Dickinson Jenkins. "The Craftsman's Art: Armenians and the Growth of Photography in the Near East (1856-1981)" (M.A. thesis, American University of Beirut, 1981).

Ortayl1, İlber. Son Imparatorluk Osmanlı [The Last Empire: Ottoman Empire]. Istanbul: Timaş Press, 2006.

Ousterhout, Robert. "Ethnic Identity and Cultural Appropriation in Early Ottoman Architecture." Muqarnas Volume XII: An Annual on Islamic Art and Architecture. Leiden: E.J. Brill, 1995.

Özel, Zuhal. "Non-Muslim Photographers of Ottomans to Early Republic Period." Kontrast, August 16, 2016. Accessed June 11, 2017. http://kontrastdergi.com/osmanli-imparatorlugundancumhuriyete-gayrimuslim-fotografcilar/.

Özendes, Engin. Abdullah Frères, Ottoman Court Photographers. Istanbul: Yapi Kredi Publications, 1998. 
Özendes, Engin. From Sébah \& Joaillier to Foto Sabah: Orientalism in Photography. Istanbul: Yapi Kredi Publications, 1999.

Özendes, Engin. Photography in the Ottoman Empire, 1839-1919, 1st edn. Istanbul: Haset, 1987 2nd edn. Istanbul: Iletisim, 1995.

Perez, Nissan N. Focus East. Early Photography in the Near East 1839-1885. New York: Abrams, 1988.

Shaw, Wendy. "Ottoman Photography of the Late Nineteenth Century: An 'Innocent' Modernism?” History of Photography 33, (2009): 80-93.

Sheehi, Stephen. The Arab Imago: Social History of Portrait Photography. Princeton: Princeton University Press, 2016.

"The Role of Armenians in Ottoman Photography." Bolsohays News, November 15, 2011. Accessed April 30, 2017. http://www.bolsohays.com/yazar-105/osmanli-fotografciligindaermenilerin-rolu.html.

Waley, Muhammad Isa. "Images of the Ottoman Empire: The Photograph Albums Presented by Sultan Abdulhamid II." British Library Journal 17 (1991): 111-127.

Woodward, Michelle. "Between Orientalist Clichés and Images of Modernization: Photographic Practice in the Late Ottoman Era." History of Photography 27 (2003): 363-374. Accessed April 30, 2017. http://www.mwoodward.com/HistoryPhotography_Woodward.pdf.

Vaczek, Louis Charles and Gail Buckland. Travelers in Ancient Lands: A Portrait of the Middle East, 1839-1919. Boston: New York Graphic Society, 1981. 